\title{
Review of Green and Sustainable Public Procurement Towards Circular Public Procurement
}

\author{
Sönnichsen, Sönnich Dahl; Clement, Jesper
}

\author{
Document Version \\ Accepted author manuscript \\ Published in: \\ Journal of Cleaner Production \\ DOI: \\ 10.1016/j.jclepro.2019.118901 \\ Publication date: \\ 2020

\section{License \\ CC BY-NC-ND}

Citation for published version (APA):

Sönnichsen, S. D., \& Clement, J. (2020). Review of Green and Sustainable Public Procurement: Towards Circular Public Procurement. Journal of Cleaner Production, 245, [118901].

https://doi.org/10.1016/j.jclepro.2019.118901

Link to publication in CBS Research Portal

\section{General rights}

Copyright and moral rights for the publications made accessible in the public portal are retained by the authors and/or other copyright owners and it is a condition of accessing publications that users recognise and abide by the legal requirements associated with these rights.

Take down policy

If you believe that this document breaches copyright please contact us (research.lib@cbs.dk) providing details, and we will remove access to the work immediately and investigate your claim. 


\section{Review of Green and Sustainable Public Procurement: Towards Circular Public Procurement}

\section{Sönnich Dahl Sönnichsen and Jesper Clement}

Journal article (Accepted manuscript*)

\section{Please cite this article as:}

Sönnichsen, S. D., \& Clement, J. (20२०). Review of Green and Sustainable Public Procurement: Towards Circular Public Procurement. Journal of Cleaner Production, 245, [118901].

https://doi.org/10.1016/j.jclepro.2019.118901

DOl: https://doi.org/10.1016/j.jclepro.2019.118901

* This version of the article has been accepted for publication and undergone full peer review but has not been through the copyediting, typesetting, pagination and proofreading process, which may lead to differences between this version and the publisher's final version AKA Version of Record.

Uploaded to CBS Research Portal: July २०२०

(C) २०19. This manuscript version is made available under the CC-BY-NC-ND 4.0 license http://creativecommons.org/licenses/by-nc-nd/4.0/ 


\section{Journal Pre-proof}

Review of green and sustainable public procurement: Towards circular public procurement

Sönnich Dahl Sönnichsen, Jesper Clement

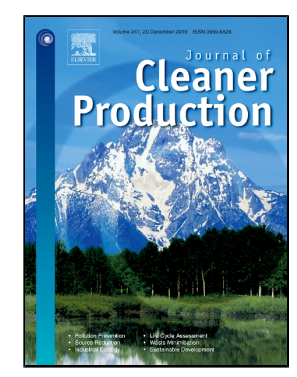

PII:

S0959-6526(19)33771-0

DOI:

https://doi.org/10.1016/j.jclepro.2019.118901

Reference:

JCLP 118901

To appear in:

Journal of Cleaner Production

Received Date:

17 May 2019

Accepted Date:

14 October 2019

Please cite this article as: Sönnich Dahl Sönnichsen, Jesper Clement, Review of green and sustainable public procurement: Towards circular public procurement, Journal of Cleaner Production (2019), https://doi.org/10.1016/j.jclepro.2019.118901

This is a PDF file of an article that has undergone enhancements after acceptance, such as the addition of a cover page and metadata, and formatting for readability, but it is not yet the definitive version of record. This version will undergo additional copyediting, typesetting and review before it is published in its final form, but we are providing this version to give early visibility of the article. Please note that, during the production process, errors may be discovered which could affect the content, and all legal disclaimers that apply to the journal pertain.

(C) 2019 Published by Elsevier. 


\title{
Review of green and sustainable public procurement:
}

\section{Towards circular public procurement}

\section{Authors: Sönnich Dahl Sönnichsenª and Jesper Clement ${ }^{\mathrm{b}}$}

${ }^{a}$ PhD fellow, Copenhagen Business School, Department of Marketing, Solbjerg Plads 3, 2000 Frederiksberg, Denmark, sds.marktg@.cbs.dk

${ }^{b}$ Associate professor, Copenhagen Business School, Department of Marketing, Solbjerg Plads 3, 2000 Frederiksberg, Denmark,jc.marktg@.cbs.dk

\begin{abstract}
This paper provides a comprehensive literature review of preliminary publications on green and sustainable public procurement from the year 2000 until now. The aim of the review is to organise, evaluate and identify patterns and clusters in published articles, providing an overview of the state of the art in green and sustainable public procurement. Classification of the data identified three overall themes: organisational aspects, individual behaviour and operational tools, which comprise nine sub-categories: three organisational, two behavioural and four operational. The review shows how awareness and knowledge of circular public procurement attributes, based on circular policy and strategy implementation, are essential to conduct circular public procurement. The procurer's beliefs and values are of high relevance in a transformation towards circular public procurement, simply not going for the lowest price, but finding an optimum combination that includes risk, timeliness and cost for the public institution on a life-cycle basis. Eco-labels, standards, life cycle assessments and life cycle costing are core parts of the process. Outlining the present knowledge as a foundation for future research in circular public procurement process development, this paper holds implications for both academics and procurement practitioners.
\end{abstract}

\section{Keywords:}

Green public procurement; sustainable public procurement; circular public procurement; dynamics in processes; circular economy 


\section{Review of green and sustainable public procurement:}

\section{Towards circular public procurement}

\section{Introduction}

\subsection{Demands for public procurement based on circular economic principles}

In light of current consumption, resource and climate changes, the European Commission published in 2015 the Circular Economy Action Plan (EU, 2015), and later did the European Parliament encourage to combine knowledge of green public procurement with circular principles (EU, 2017a). The report highlights that public procurement and purchase of products, services and works amount to approximately EUR 1,800 billion, equivalent to $14 \%$ of the European gross domestic product. Further, does it describe how circular public procurement can influence markets and by that creates greener and more sustainable products and services through procurement tools and guidance. (EU, 2017a, EU, 2017b). Compared to a business as usual mode, circular public procurement practices are considered the approach able to facilitate environmentally, socially and ethically production and consumption (Rakitovac and Simokov, 2011). Yet, the adaptation and transformation towards a circular economy is in a nascent stage (Ritzén and Sandström, 2017), which is also the case for public tendering and procurement (Cheng, Appolloni, D'Amato and Zhu 2018; EU, 2017a).

Circular economic theories have evolved since the 1970s and recently received huge attention from a diverse range of stakeholders (Geissdoerfer et al., 2017). Circular economy minimizes incineration and landfill; is regenerative and restorative by design; operates by default on renewable energy; maintains resources at their highest value at all times; inherently has a higher complexity than linear transactional value chains; and thus embeds a potential to decouple growth in the extraction of virgin resource from monetary growth (Ellen MacArthur Foundation, 2013; Webster, 2017). Accordingly, the circular economy addresses the United Nations Sustainable Development Goals, specifically goals 6-9 and 11-17 (UN, 2017; Sachs et al., 2017), indicating that a circular economy helps to meet the needs of the present without compromising the needs of the future (WCED, 1987). 
Green and sustainable public procurement have likewise gained status as addressing societal, environmental and social challenges through public procurement activities. Since circular public procurement is a new field in both academia and practice, a literature review of green and sustainable public procurement, can provide insights for future circular public procurement processes. In that way, elements in green and sustainable public procurement can facilitate and develop circular public procurement processes (EU, 2017a+b). The objective of this article is therefore, to outline the state of art in green and sustainable public procurement in theory and practice, valuable for a transition towards circular public procurement.

\subsection{Similarities and differences between green, sustainable and circular public procurement}

The definition of green public procurement is: "a process whereby public authorities seek to procure goods, services and works with a reduced environmental impact throughout their life cycle when compared to goods, services and works with the same primary function that would otherwise be procured" (EU Com, 2016). While sustainable public procurement is defined as: "a process whereby organizations meet their needs for goods, services, works and utilities in a way that achieves value for money on a whole life basis in terms of generating benefits not only for the organization, but also for the society and the economy, whilst minimizing damage to the environment" (UNEP, 2013, p. 11). The European Commission defines circular public procurement as: "the process by which public authorities purchase works, goods or services that seek to contribute to closed energy and material loops within supply chains, whilst minimising, and in the best case avoiding, negative environmental impacts and waste creation across their whole life-cycle" (EU, 2017b, p. 5). The three types of procurement have similarities that raise the level of complexity in public procurement, compared to tendering and procuring scenarios based on purchase at the lowest up-front price.

The only academic review of green public procurement published to date, is a study by Cheng, Appolloni, D'Amato and Zhu (2018) outlining missing concepts and future trends. Their analysis showed how green public procurement research mainly have focused on the specific impacts of green public procurement implementation. The authors stated that green public procurement is still in its infancy as a policy tool in relation to green innovation. Their review revealed a changed focus from general concepts to specific areas. 
Before 2013, the literature chiefly focused on procurement processes, whereas from 2013 to 2016, the focus moved towards practice and impact. Yet, insight in the managerial and institutional dynamics, that are able to support and implement circular public procurement practices, have not yet been outlined.

By outlining three categories of focus in extant academic literature, this review provide relevant insights for development and implementation of circular public procurement. Furthermore, the review tries to outline the gaps in literature and by that pointing at directions for future research. However, due to the limited body of literature available on circular public procurement, this review takes its point of departure in research on green and sustainable public procurement. A perspective supported by Alhola and colleagues (2018) finding several opportunities and connections between promoting circular economic principles and green and sustainable public procurement policies and criteria. Due to the similarities of the three concepts, the aim of this review is to analyse shared complex features of green, sustainable and circular public procurement. For reasons of semantic simplification, the remainder of this paper does not distinguish between the concepts but refer to them collectively as circular public procurement.

The remainder of this paper structures as follows. Section 2 outlines the underlying methods for the literature search, delimitations and coding structure. Section 3 provides knowledge on findings comprising organisational aspects, issues related to individual behaviour and operational tools in relation to circular public procurement processes, including managerial implications. Finally, section 4 finalizes the literature review with concluding remarks, limitations and calls for further research.

\section{Method}

The aim of a literature review is to organise and identify patterns in recently published articles providing best-evidence overview (Noguchi, 2006). In this case, a state of the art of green, sustainable public and circular public procurement (McInnis, 2011) is obtained by a structured search process and a transparent analysis of current literature (Seuring and Muller, 2008; Rousseau et al., 2008). In particular, the objective of this review is, through synthesis using current research as its basic unit of analysis (Corbin and Strauss, 
1990; Saldana, 2013), to build a theoretical conceptual framework, highlighting how dynamics in circular public procurement processes might influence the outcomes.

The following academic databases were used in the literature search: EBSCO Host - Business Source Complete, Scopus, Google Scholar and ProQuest to enable systematic collection of data from recognised databases and to create high internal validity. Keywords such as; green public procurement, sustainable public procurement and circular public procurement were used in order to find relevant articles. Only two articles (Alhola et al., 2018; Witjes and Locano, 2016) were found under the keywords circular public procurement, and other papers were found under green and sustainable public procurement. Papers conceptually comparable to circular public procurement processes.

The literature review protocol is designed to achieve three main goals: 1) a broad and comprehensive overview of previous findings on circular public procurement; 2) robust, reliable and valid research findings; and 3) a geographic area limited to Organisation for Economic Co-operation and Development countries due to their cultural and contextual similarities. We extracted 162 papers from the database in December 2018, covering 2000 to 2018. After applying the three goals just mentioned, 53 articles remained, published in journals ranging from $\mathrm{A}$ to $\mathrm{C}$ on the AJG list. Out of the 53 articles, 23 used quantitative methods, 27 qualitative, and three made use of mixed methods. The literature search omitted papers that were published in languages other than English; had a descriptive or normative approach; showed inconsistencies regarding epistemology, ontology and methodology that reduced their reliability and validity; were narrow in their technical specificity; were books, book chapters or book reviews; and finally, papers that showed no connection to green, sustainable or circular public procurement.

The purpose of the initial coding cycle was to find narrative structures of the literature in order to optimise the data analysis procedure and to detect conceptual patterns and variations in the data (Saldana, 2013). In accordance with basic theory, the initial coding process was open-ended, starting with an interpretive process at data level, analytically comparing studies to identify similarities, differences, sequences, and causations (Corbin and Strauss, 1990). In order to facilitate a streamlined essence-capturing codification process, the 
authors started by separately classifying the included papers in meaning clusters, which were based on the phenomenon under scrutiny in each paper (Saldana, 2013). The majority of papers had a very clear objective of their study and the emerging classification was straightforward. The second coding cycle involved simultaneous coding, in order to label concepts and to establish and verify meaning clusters (Ringberg and Gupta, 2003), and from which sub-categories emerged (Saldana, 2013). The remaining papers was discussed among the authors and a common understanding developed for allocating these papers to either the created clusters or for making new sub-categories. All coding and categorisation were made by hand, not relying on software for structuration, and to force an in-depth relation to the papers under scrutiny. The coding cycles thus captured the essence of knowledge, within the underlying sub-categories able to describe subtle and tacit areas (Saldana, 2013).

\section{Results}

The initial analysis and structuring of the literature identified a variety of first-order concepts that was allocated to three main categories and further nine sub-categories. The first main category comprises organisational aspects and contains three sub-categories: 1) size, 2) strategy and top-level management and 3) policies and the quality of contracts. The second main category is the individual behaviour, which has two sub-categories: 1) agency and cross-departmental management and 2) beliefs, awareness and individual guidance. The final main category is operational tools and comprises of four sub-categories: 1) process and prioritisation tools, 2) calculation and criteria setting tools, 3) standards, standardisation and legal aspects and 4) supplier selection. Table 1 provides an overview of the three categories and their sub-categories together with the related articles and the methods employed. Further, tables 2-10 comprise information as a summary of the corresponding sub-category.

\begin{tabular}{llll}
\hline Themes and sub- & Authors & Method \\
categories & & \\
&
\end{tabular}




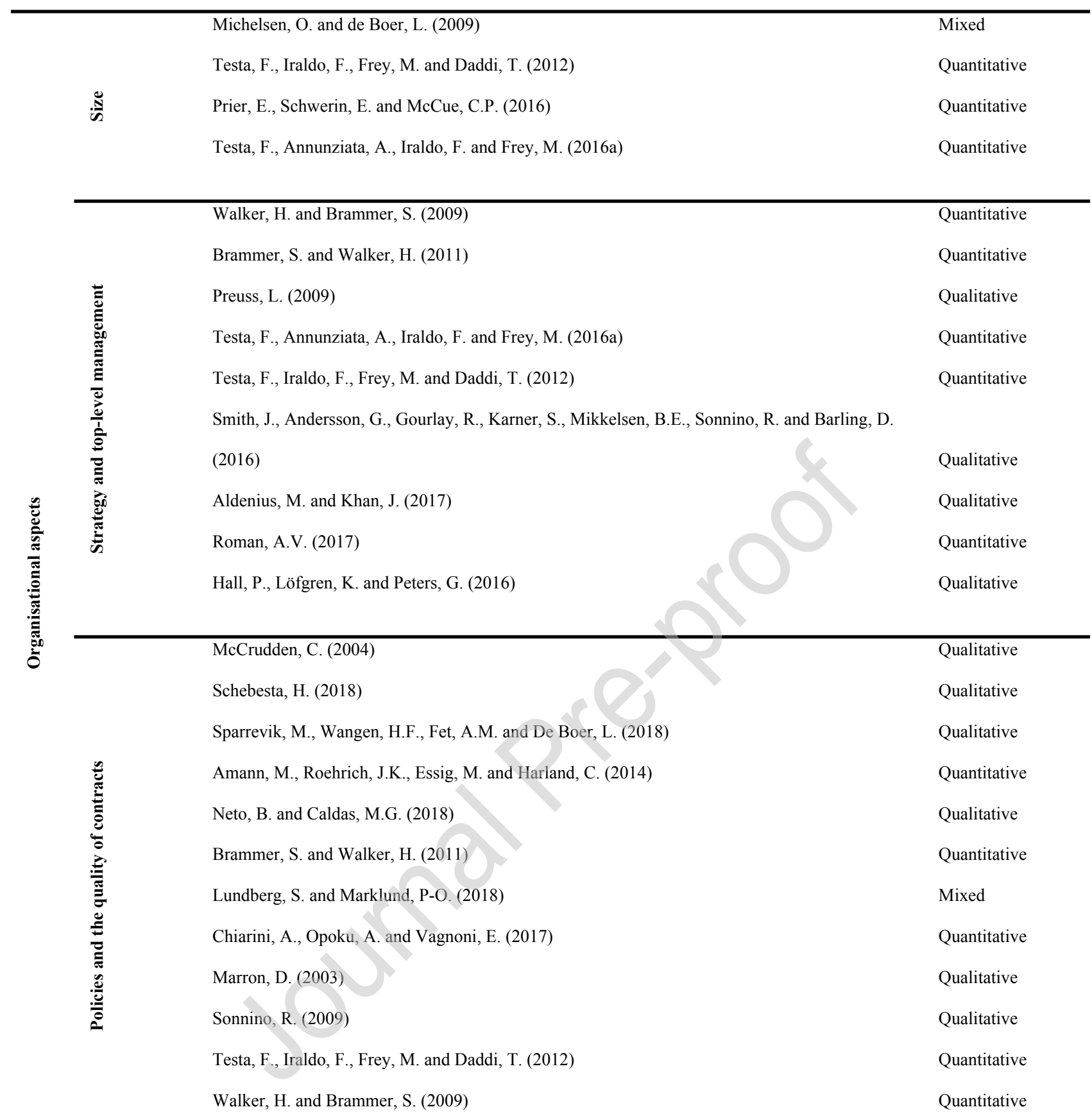




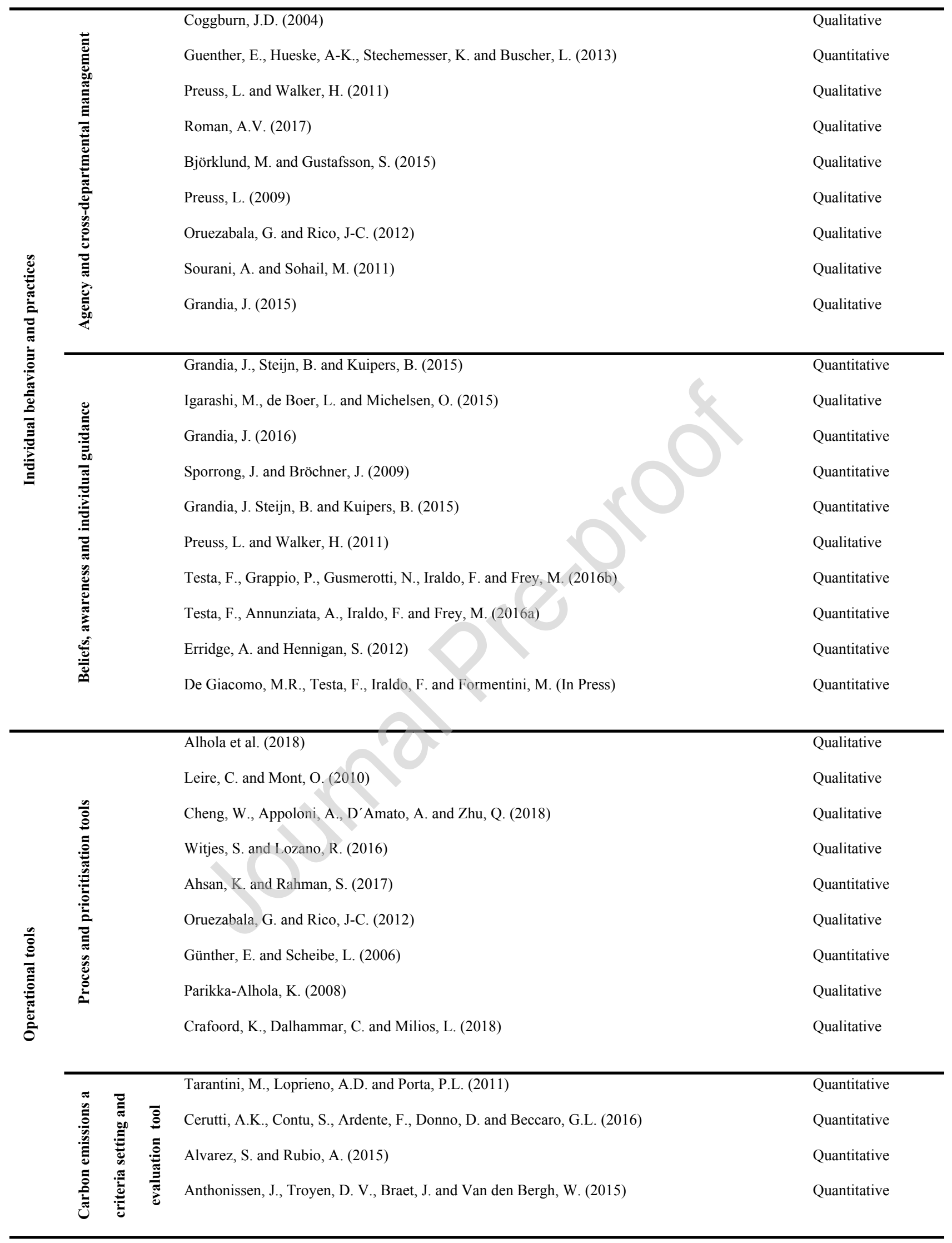




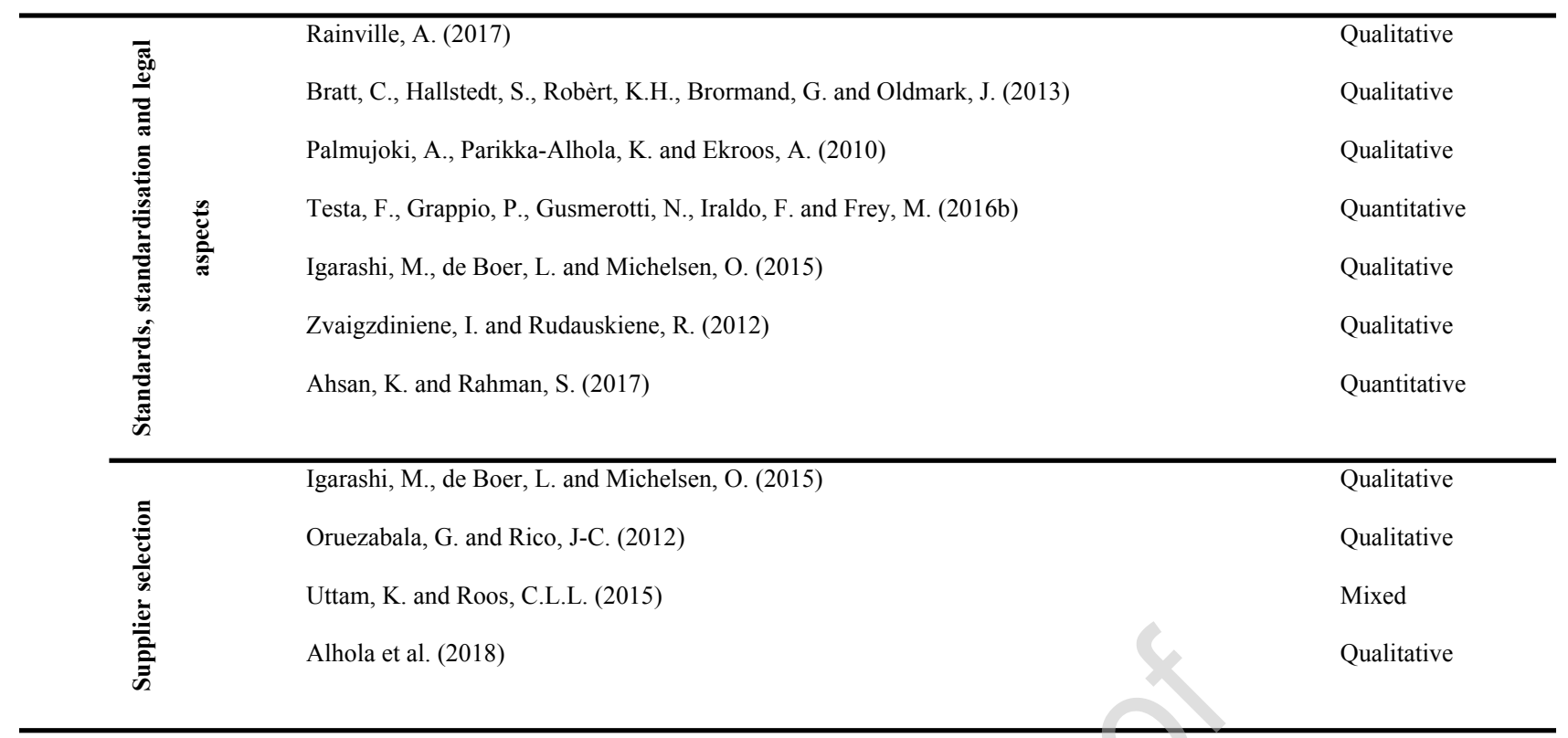

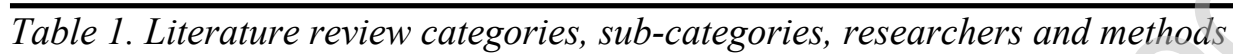

It is relevant to emphasise that additional factors can influence the procurement process. Yet, factors not underpinned by peer-reviewed empirical or theoretical research are not included here. The following sections outlines the three major category and their related sub-categories one by one. After each subcategory, a table will summarise the relevant aspects.

\subsection{Organisational aspects}

The category organisational aspects comprises three sub-categories: Size, Strategy and top-levelmanagement and Policies and quality of contracts (Table 1). This section outlines how size of the procuring organisation effect circular procurement processes implementation (Table 2). Further, the importance of paying attention to the influence of a strategic foundation and top-level management's engagement in providing direction based on circular economic principles (Table 3). Lastly, the relevance and impact on quality of contracts, through policy implementation enhancing circular economic principles (Table 4). The papers included in the category divides between qualitative and quantitative equally and a two are using mixed methods (Table 1). 


\subsubsection{Size}

Two studies examine the role of knowledge, organisational size as the actual effects on environmental criteria in purchasing decisions, and find that circular public procurement is more established in large municipalities compared to smaller ones. It is emphasized that size of the public authorities and the level of awareness of the existing tools for supporting circular public procurement, result in an overall positive and significant effect on the probability that public authorities adopt circular public procurement practices (Michelsen and de Boer, 2009; Testa et al., 2012). Even though it is argued, that size does matter in relation to probable implementation of circular public procurement, do the majority of potential suppliers and public authorities state, that environmental criteria have never caused the offer with the lowest price to be rejected (Michelsen and de Boer, 2009).

Assessing the impact of the scope and reach of a public authority's size suggesting, that if public authorities employ circular public procurement, it is because of random, cautious, unsystematic patterns of experimentation. This indicates that public authorities do not pursue circular public procurement aggressively, and that the size and level of the procurement organisation does not affect efforts to embrace circular public procurement. Prier et al. (2016) further suggest that smaller organisations are also capable of utilizing green purchasing practices. Circular public procurement practices do only contribute to sustainability developments at the local level if the local authorities undertake a path, which raises awareness of circular public procurement strategies and fully integrates circular public procurement objectives into its organisation by carrying out considerable changes at cultural, managerial and operational levels (Testa et al., 2016a).

This raises the issue of whether circular public procurement is more established in some institutional settings than others because of organisational size. Even though small public authorities may face higher barriers in developing circular public procurement initiatives, another possible contributing factor includes the lack of capabilities to define, within the organisational boundaries, proper responsibilities, roles and functions needed to deal with circular public procurement challenges (Testa et al, 2012). These issues, however, are not necessarily restricted to small institutions. Small public authorities may be restricted by the amount of 
resources they can devote and allocate to detailed circular public procurement if for example, the procuring unit only consists of a part-time position.

On the other hand, factors such as conceiving, designing and implementing organisational solutions and new functional models do also play a role. Additional research is necessary to analyse and develop solutions and models, which can enable all sizes of public authorities to develop high-profile circular public procurement decision making, by applying interdisciplinary and technical knowledge. In order to define the proper responsibilities, roles and functions for procurers, the development of capabilities dealing with challenges of circular public procurement should be established (Testa et al., 2012).

\begin{tabular}{|lll|}
\hline \multicolumn{1}{|c|}{ Sub-category: Size } & Authors \\
\hline - & $\begin{array}{l}\text { Circular public procurement is more established in large organisations } \\
\text { compared to smaller }\end{array}$ & Michelsen and de Boer (2009); \\
- & Testa et al (2012) \\
Size and level of the procuring organisation does not affect efforts of pro- & Prier et al. (2016) \\
- $\begin{array}{l}\text { Inclusion of circular public procurement is a result of random, cautious } \\
\text { and unsystematic experimentation patterns }\end{array}$ & Prier et al. (2016) \\
- $\begin{array}{l}\text { Raising awareness of proper responsibilities, roles and functions on all } \\
\text { organisational levels is imperative to deal with challenges }\end{array}$ & Testa et al. (2012) \\
- $\begin{array}{l}\text { Considerable cultural, managerial and operational changes contribute to } \\
\text { development at local level }\end{array}$ & Testa et al. (2016a) \\
- A lack of organisational capabilities, proper responsibility and \\
roles/functions is a barrier to implementation \\
Smaller public institutions can conceive, design and implement \\
$\begin{array}{l}\text { organisational circular public procurement solutions but are challenged by } \\
\text { internal resource allocation }\end{array}$
\end{tabular}

Table 2. Organisational aspects of size

\subsubsection{Strategy and top-level management}

This subcategory on strategy and top-level management outlines informational organisational aspects, financial aspects, organisational attitudes and the availability of sustainably products and services, addressing the issues of transparency, accountability, and the societal and environmental obligations of 
public authorities. Findings suggest, that the strategic perspective is more focused on supporting local suppliers than the overall systemic advantages of circular public procurement and that the most important facilitator of circular public procurement is organisational top management support (Walker and Brammer, 2009). Leadership is an important factor in the implementation of circular public procurement in public sector organisations. If senior managers are supportive towards circular public procurement and incorporate the aforementioned issues in organisational of planning, strategies and goal setting, the purchasing team will be more likely to implement circular public procurement (Brammer and Walker, 2011). Facilitators, such as support from top management, are addressed in a more detailed study on political strategies, finding that effective facilitators at political, administrative, cultural and commercial levels are crucial to build the context for conducting circular public procurement. Specifically highlighting clear political goals, allocation of funding towards change within a given timeframe, cross-departmental commitment and co-operation under budget constraints, are imperative to successful implementation of circular public procurement (Smith et al., 2016). Underlining the importance of political strategic ambitions and supporting top-level management in creating and maintaining continuity, are necessary to create effective circular public procurement processes. A clear mandate towards circular public procurement, along with training, needs to come from top-level management, and be aligned with the organisation's strategies and objectives, in order to address the challenges of budget constraints and risk perception related to biased price perceptions in circular public procurement and tendering.

An analysis of transparency, strategy, culture and risk management that examined circular public procurement from an organisational supply chain management perspective, uncovered a range of initiatives that local councils have undertaken to address the economic, social and environmental aspects of sustainability. Some of those initiatives included encouraging first-tier suppliers to make use of small local businesses as subcontractors (economic), contracting with voluntary organisations (social) and replacing hazardous materials in products and services (environmental). Moreover, it was asserted that the most salient barrier to the implementation of circular public procurement, is the financial pressure related to a general perception, that buying green and sustainable products involves higher prices at the point of purchase 
(Preuss, 2009). This perception is often caused by budget constraints (even cuts), experienced by procurement practitioners in the quest to deliver value for money.

However, creating awareness and knowledge of what circular public procurement oriented strategy can accomplish in the long-term, may lead to a shift in the approach purchasers take, moving from a focus on the point of purchase cost to life-cycle costing, which in turn may lead to a more effective management of public resources. This emphasize, that more research is recommended, in order to understand the effects of circular public procurement on economic systems (Testa et al., 2016a). Further, an exploration of how organisational top-level demands emphasising circular public principles can direct firms supply chain management strategies into greener development paths, promote resource savings and green innovation, and mitigate financial pressure (Testa et al., 2012).

In relation to the findings of organisational strategy and the relevance of top management as a facilitator of circular public procurement, studies show how circular public procurement is used in relation to five influential organisational factors: strategies, requirements, costs, size and knowledge. Findings, highlight that the level of influence and knowledge of top management are essential in support of facilitating circular public procurement strategies. How rigidly the requirements are set, is closely connected to these strategic issues, and these findings suggest that functional requirements would be the most cost-effective tender tool. However, it is also highlighted that it is difficult for local authorities to enhance innovation in specific technologies when they strategically wish to do so, unless they have specific requirements or very detailed functional requirements (Aldenius and Khan, 2017). In addition, the results reveal, that only the largest geographical region found it possible to influence market development, which is a relevant insight with market development and innovation considered as central to the circular economic strategy initiated by the European Commission.

Research also indicates that a direct factor able to influence the outcome of circular public procurement, is an imperative for greening procurement coming from through political commitment, environmental knowledge and the organisational structure of the focal government and the focal interpretation of the regulatory 
framework (Hall et al., 2015). The authors see this as stronger than any indirect support through European and national soft regulation or policy advice.

In the next section, an example comparing UK and Italy will be elaborated to demonstrate the differences in interpretation of possibility factors. Results show that, a decentralised structure hold the opportunity to embrace circular public procurement. However, it requires committed politicians, engaged public officials and an optimal level of internal organisational support structures comprising knowledge of circular principles and enabling rules (Hall et al., 2015). A study on public sector management addressing the adaptation of circular public procurement at the organisational level looked into factors that lead an organisation to adopt sustainable practices while drawing on system, stakeholder and institutional theory and transformational leadership (Roman, 2017).

The findings support the idea, that the transformational managerial style of an organisation's top executives, stakeholder expectations and organisational innovativeness, influence the institutionalisation of sustainable practices. Centralisation of decision-making might not directly influence the strategic role, but instead have a negative impact on the degree of interdepartmental collaboration and institutional innovativeness (Roman, 2017). It is interesting, how fragmentation in the form of out-sourcing the procurement function or hiring consultants is definitely not recommended. Nor is overly radical decentralisation, since fiscal constraints will most likely take the upper hand in the procurement of discrete departments (Hall et al., 2015).

In other words, the notion of top-level engagement as an internal organisational driver, but also the effects of knowledge, the external legal aspects, the level of (de)centralisation, and the role of third-party stakeholders are addressed as possible drivers and barriers for circular public procurement. For practitioners, the literature suggests, that awareness and knowledge are the main drivers for developing effective circular public procurement procedures. These main drivers are one of the key factors in designing and implementing strategies successfully by allocating resources devoted to supporting and maintaining a knowledge-based organisation. For instance, training procurement professionals in the use of environmental criteria, is found to be crucial in magnifying opportunities (Testa et al., 2016a), and from which it follows, that the 
organisational structures must be able to deliver information and training for staff involved in circular public procurement related tasks.

\begin{tabular}{|c|c|}
\hline Sub-category: Strategy and top-level management & Authors \\
\hline $\begin{array}{l}\text { Strategic perspectives are more focused on support to local suppliers than } \\
\text { the overall systemic advantages }\end{array}$ & Walker and Brammer (2009) \\
\hline $\begin{array}{l}\text { - Senior managers should incorporate circular public procurement planning, } \\
\text { strategies and goal setting to support the purchasing team }\end{array}$ & Brammer and Walker (2011) \\
\hline $\begin{array}{l}\text { - Awareness and knowledge on long-term effects can shift perception of the } \\
\text { impact and approach }\end{array}$ & Testa et al. (2016a) \\
\hline $\begin{array}{l}\text { - Financial pressure related to perception of higher prices when buying } \\
\text { circular value offers }\end{array}$ & Preuss (2009) \\
\hline $\begin{array}{l}\text { Clear political goals, allocation of funding towards change, cross- } \\
\text { departmental commitment and co-operation under budget constraints } \\
\text { imperative }\end{array}$ & Smith et al. (2016) \\
\hline - Influential factors: strategies, requirements, costs, size a & Aldenius and Khan (2017) \\
\hline - Indirect support: EU and national soft regulation & Hall et al. (2015) \\
\hline $\begin{array}{l}\text { Direct support: political commitment, environmental knowledge, } \\
\text { organisational structure of focal government and focal interpretation of } \\
\text { regulatory framework }\end{array}$ & Hall et al. (2015) \\
\hline $\begin{array}{l}\text { - Transformational top-level managerial style, stakeholder expectations and } \\
\text { innovativeness influence institutionalisation }\end{array}$ & Roman (2017) \\
\hline $\begin{array}{l}\text { Education of purchasing professionals in the use of circular public } \\
\text { procurement criteria crucial to magnifying opportunities }\end{array}$ & Testa et al. (2016a) \\
\hline $\begin{array}{l}\text { - Out-sourcing of procurement function nor radical decentralisation is } \\
\text { recommended }\end{array}$ & Hall et al. (2015) \\
\hline
\end{tabular}

Table 3. Organisational aspects of strategy and top-level management

\subsubsection{Policies and the quality of contracts}

The third organisational subcategory is the effect of policies and quality of contracts, looking into how the implementation of policies can mitigate perceived risk during decision-making processes. During the nineteenth and twentieth centuries, several international linkages have existed between public contracting and social regulation (McCrudden, 2004). Public procurement regulations have generally been characterised 
by a tension between budgetary considerations and the objective of other considerations related to environmental and social aims (Schebesta, 2018).

Financial concerns are confirmed as the biggest barrier to implementing circular public procurement because public procurers appear to resist paying extra for environmental and social aspects. However, if governmental policy and legislation are supportive of circular public procurement, public sector organisations are more likely to implement circular public procurement (McCrudden, 2004). A case study revealed how the integration of policy requirements in the formal management of a project, resulted in successful implementation of circular public procurement in the purchase of an energy net-zero building project (Sparrevik et al., 2018). Policymakers thus need to be mindful towards the emphasis they place on various aspects of circular public procurement, if they wish to enhance a more sustainable public agenda.

An examination of the connections between sustainability policy goals in public tenders and their achievements through contract awards shows, that the integration of environmentally and socially responsible policy goals in public tenders, results in bidders integrate the required criteria in their offer (Amann et al., 2014). Consequently, including environmental and social policy indicators in tenders can thus enhance the effectiveness and quality of the circular public procurement outcome if included as specific requirements. Analysis shows that some criteria receive more attention than others do, such as organic production, seasonal and fresh produce, transportation and packaging, menu planning, staff training, waste management and animal welfare in food and catering (Neto and Caldas, 2018). Yet, adding specific requirements to tenders also requires more compliance control in the contract period, which increases transaction costs. Doing so, favours large companies with more resources in terms of developing tenders compared to small and medium-size enterprises.

Practical insights in the implementation of governmental circular public procurement policies additionally show, that the extent and nature of circular public procurement policies vary significantly across regions. Most public sector organisations embed some circular public procurement criteria in their procurement process, although some aspects of green and sustainable issues are neglected (Brammer and Walker, 2011). 
To enhance effectiveness, policymakers should consider developing guidance on how to integrate the environmental, social and economic impact of circular public procurement in knowledge dissemination, because the realisation of circular public procurement requires full engagement of all involved parties. From this, it follows that public authorities can enhance the effectiveness of inducements for suppliers when considering the full extent of the environmental and social policy targets within their tenders. Findings show, that inclusion of policy goals in the procurement process can explain up to $50 \%$ of the variation of why suppliers considers circular criteria in their production of products and services (Amann et al., 2014). However, following the argument that more criteria would require more complex auditing of compliance, it is necessary to find a balance with fewer, but more stringent, criteria, which is supported by results indicating that only one policy objective should be employed per instrumental criterion to allow circular public procurement to have a positive impact (Lundberg and Marklund, 2018).

Even though public standards and performance criteria are based on the same legislation and regulations, empirical findings indicate that differences occur. UK organisations, for example appear to have the propensity to request suppliers to improve environmental performance over time and comply with voluntary, social accountability standards, including their carbon footprint. Opposed to this, Italian organisations seem to be more focused on respecting mandatory environmental and safety laws and regulations. This indicates a relevance of analysing how national and international standards influence their impact, along with a focus on how policies influence the level of circular public procurement adoption (Chiarini et al., 2017).

On this background it is argued, that to mitigate the organisational perception of risk when conducting circular public procurement do support from adopted circular public procurement policies, acts as a strong facilitator for managers, underlining the importance of a clear mandate and direction from policymakers. Strategic political ambitions that provide top management with a clear mandate creates continuity, which is central in the effort to learn and conduct effective a circular public procurement process. Moreover, the political level of engagement and commitment is important in leveraging the circular public procurement process to support public authorities in the pursuit of effectively changing public consumption patterns to become more circular. It is further argued, that at least top management should be trained and equipped with 
knowledge derived by research and awareness of the different possible tools available to enhance the processual skills of the circular public procurement process. Tools are necessary for modelling/calculating the economic, social and environmental gains in a life-cycle perspective, not solely focusing on the lowest price. Through awareness and knowledge of circular economic principles connected to the organisational strategy, will the perceived risk in the process of entering a new domain decrease.

By evaluating circular public procurement relative to other environmental policy instruments, three potential economic justifications are identified for circular public procurement initiatives. The first one is structural inefficiencies in public purchasing, while the second involves adjusting insufficient environmental regulations. The third one is regulating insufficient public and private support for innovation. The second justification is the only one, having distinct implications for environmental policy design relative to other environmental instruments. It is also the most promising, if the public body is the primary source of demand (Marron, 2003). Initiatives for greening markets have the least impact if the focus is merely on the substitution of existing brown products for green products. Circular public procurement will be most effective with a focus on new solutions that the private sector finds reason to adopt. However, the latter is contested by findings highlighting, that the adoption of specific certification labels by the public sector are imitated by private companies and demand (Schebesta, 2018). An area that calls for further research to understand the transformational opportunities greening markets offer. Implementation of procurement policies and their effectiveness in change processes is further analysed through the relationship between the quality of contracts and negotiation power in food chains.

Results show that the quality of contracts is an outcome of a contingent process of negotiation, which entails and determines the power relationships among stakeholders. Underlining that public policy goals in relation to triple-bottom line objectives, has the potential to create an economy of quality that adds economic, environmental and social benefits to sustainable societal development (Sonnino, 2009). An important aspect is that circular public procurement criteria must be embedded in broader policy initiatives to incentivise contracting authorities to incorporate more tender specifications that rely on circular public procurement criteria (Schebesta, 2018). Developing awareness through intensive training on tender procedures, defining 
requirements, qualifying suppliers and identifying the best value for money tenders in a circular public procurement context, is a complex task that requires a high degree of cross-sectoral interdisciplinary collaboration (Testa et al., 2012). Policymaker plays a central role, and results indicate that circular public procurement is more effective to influence socially responsible policy goals than environmental ones. Thus, these studies also suggest, that political engagement and commitment in leveraging the process of circular public procurement, are highly relevant in the pursuit of holistically implementing circular public procurement practices (Amann et al., 2014). In particular, familiarity with policies, perceived inefficiencies/cost of policy, supplier availability/resistance and organisational incentives/pressures are four barriers that require additional research (Walker and Brammer, 2009).

To develop an effective circular public procurement tender contract, the public authorities need to enhance capabilities by training technical, legal and financial skills. The technical skills must be developed in regards to environmental criteria and their application for product categories, and legal must be improved in relation to evaluate the environmental value of the tender in order to integrate this value in the monetisation of the price. On an organisational level, policy goals should support the incorporation of circular economic parameters in the tender process as quality parameters. Market dialogue and shared experiences in interdisciplinary iterative processes of negotiation between suppliers, contractors and other relevant stakeholders can enhance these policy goals (Testa et al., 2012).

\begin{tabular}{|lll|}
\hline \multicolumn{2}{|c|}{ Sub-category: Policies and the quality of contracts } & \multicolumn{1}{c|}{ Authors } \\
\hline - $\begin{array}{l}\text { Public procurement contracts are characterised by balancing budgetary } \\
\text { considerations and objectives of environmental and social aims }\end{array}$ & Schebesta (2018) \\
- $\begin{array}{l}\text { Policymakers should mindfully emphasise circular public procurement } \\
\text { - } \begin{array}{l}\text { Policy goals in tenders result in integration of required criteria in tender } \\
\text { offers }\end{array}\end{array}$ & $\begin{array}{l}\text { Amann et al. (2014); Sparrevik et } \\
\text { al. (2018) }\end{array}$ \\
- National differences in application and interpretation of legislation and & Chiarini et al. (2017) \\
regulation (mandatory vs. voluntary) & \\
- Criteria's receive different attention according to the context of contracts - & $\begin{array}{l}\text { Brammer and Walker (2011); Neto } \\
\text { tendency that some criteria get neglected }\end{array}$ & and Caldas (2018) \\
\hline
\end{tabular}




\begin{tabular}{|c|c|}
\hline $\begin{array}{l}\text { - Most effective to create new/innovative solutions, if objective is to } \\
\text { change/develop markets }\end{array}$ & Marron (2003) \\
\hline Public use of specific certifications is imitated by private demand & Schebesta (2018) \\
\hline $\begin{array}{l}\text { Quality of contracts is an outcome of contingent processes of negotiation, } \\
\text { determining power relations }\end{array}$ & Sonnino (2009) \\
\hline $\begin{array}{l}\text { Market dialogue and shared experiences occur through interdisciplinary } \\
\text { iterative processes }\end{array}$ & Testa et al. (2012) \\
\hline
\end{tabular}

Table 4. Organisational aspects of policies and the quality of contracts

\subsubsection{Conclusion on the organisational aspects}

In summary, some issues regarding the organisational aspects are similar across sub-categories and others are distinctively only related to a specific sub-category. Awareness and knowledge through education, training and clear political goals are all crucial to enhance circular public procurement and to support effectiveness in the tender process. Thus, organisational structures must be able to deliver information. The issue of awareness and knowledge is highlighted in the discussion of whether size matters. The size of the procuring organisation do not necessarily affect efforts towards effective use of circular public procurement. However, this is the case if internal resource allocation actually supports increasing organisational capabilities towards understanding circular public procurement opportunities.

Inclusion of circular public procurement principles is often a result of random, cautious and unsystematic patterns of experimentation. To achieve an effective use of circular public procurement implies a focus on developing cultural, managerial and operational structures, able to support systematic and focused processes. The integration of circular public procurement objectives in organisational strategies are clearly imperative in the effort to prevent a lack of organisational capabilities, proper responsibility and functional roles from acting as barriers for large and small public organisations. Transformational senior managers should incorporate organisational circular public procurement planning, strategies, cross-departmental commitment and goal setting, which should further be supported by political, administrative, cultural and funding measures to enhance effective implementation of circular public procurement processes. 
Public procurers are often resistant to pay a price premium to include circular public procurement due to budget constraints. The integration of policy goals in tenders leading to inclusion of required criteria in tenders, pushes however contractors to adopt strategic circular public procurement policies to mitigate the operational staff's risk perception. This is why policymakers should consciously emphasise circular public procurement values in operations and communication, using EU and national soft regulation as an indirectly support. In contrast, direct support comes from political commitment, environmental knowledge, the organisational structure and the focal interpretation of regulatory framework. National differences in the application and interpretation of legislation and regulations between mandatory and voluntary utilisation do also occur.

In addition, the private sector imitates the public sector regarding the use of specific certifications. If the objective of public institutions is to change markets towards more circularity, then demanding innovative new solutions have the largest impact. The quality of contracts is the result of contingent processes of negotiation, making market dialogue and sharing experiences through interdisciplinary iterative processes to be highly efficient in terms of supporting greater circularity in public purchasing. Finally, effective circular public procurement contracts are based on the enhancement of technical, legal and economic capabilities in the procurement department or staff.

\subsection{Individual behaviour and practices}

This category comprises two sub-categories: Agency and cross-departmental management and Beliefs, awareness and guidance (Table 1). The first sub-category on Agency and cross-departmental management (Table 5) outlines how implementation of circular public procurement principles rely on human agency, change agents role in collaboration and how organisational silo constructs hinder knowledge transfer. The second sub-category of Beliefs, awareness and individual guidance (Table 6), highlights the individual motivation and related behavioural aspects as essential in accomplishing effective circular economic procurement processes. The articles included in this category divides between qualitative and quantitative equally (Table 1). 


\subsubsection{Agency and cross-departmental management}

In addition to incorporating circular public procurement policy strategy and awareness of circular public procurement requirements in the tender process, the human factor has to be taken into consideration in the decision-making process. Behavioural drivers and barriers able to create incentives or prevent public procurers from acting and engaging with circular public procurement, become clear upon examination of the dynamics of the various processes. One argument is, that circular public procurement is not antithetical to the ingrained managerial values of public administrations. Circular public procurement can indeed help public agencies to accomplish a circular mission, efficiently (e.g. use of eco-labels) and economically (joint purchasing or life cycle costing assessments). Further, circular public procurement also holds great promise for improving environmental conditions (reduction of greenhouse gas emissions) efficiently and economically (Coggburn, 2004). Individual managers and employees however, might feel that there are various barriers, which can differ depending on what the circular public procurement encompasses. These barriers need to be mapped out, in order to understand and develop behaviours able to overcome perceived obstacles in circular public procurement utilization (Guenther et al., 2013).

Studies on psychological barriers and how procurers engage with visible technical, budgetary and regulatory issues in circular public procurement processes indicate, that a variety of issues hamper this progress. That is both individual factors (cognitive and affective elements), organisational factors (impact of managerial control, organisational structure and culture), small-group adaptation processes (between members of purchasing groups), adaptation processes within the organisation (intra-organisational resistance and problems in coordinating activities), and external adaptation processes between organisations (isomorphic pressure, priorities emanating from the local context) (Guenther et al., 2013).

Findings highlight, how agency embeds in relatively enduring socio-economic structures (Preuss and Walker, 2011). Individual commitment by senior management through training along with mandatory sustainable development targets, must be clarified to assist the evolution of process development. Further, changing the organisational culture in favour of greater individual engagement to sustainable development 
takes time, and it is likely to be influenced by senior management's individual commitment and the existence of champions (change agents) throughout the organisation (Preuss and Walker, 2011).

A narrow focus on separate organisational sub functions might lead to overseeing the fact, that sustainable challenges are not only technical but also encompass various human behavioural aspects. Introducing and educating dedicated internal change agents, can support such develop of an organisation (Roman, 2017). When it comes to hiring, human resource departments should focus on finding staff whose behaviour and knowledge concerning the benefits of circular public procurement, which will positively affect the inherent beliefs among other employees. Change agents play a pivotal role in developing and driving circular public procurement processes, by continuously initiating, sponsoring, directing, managing and/or implementing circular public procurement activities in project teams. In order to optimise the circular public procurement process, key actors should be encouraged to take on the role of change agents and engage procurement actors to adopt new behaviours, because the full potential of circular public procurement is difficult to achieve if organisations are unable to align their behaviour with a desired new strategy (Grandia, 2015).

Identification of the barriers can assist public clients in addressing the incorporation of sustainability in procurement strategies. Research outlines how to cope with the barriers and drivers, providing recommendations for parties to act on. Individual procurers should acquire adequate training, allocate sufficient time for circular public procurement and establish communication opportunities. Professional and educational bodies should work to raise the level of awareness on circular development across society from an overall perspective. Just as the supply chain should move towards further integration, and public agencies should stimulate demand for sustainable products.

A study of efficient coordinated freight distribution of municipal goods showed, that knowledge dissemination and collaboration are highly important to develop environmentally conscious freight distribution initiatives. These findings stressed individual information exchange and strategic knowledge transfer as paramount to success in effective city logistics during all phases of the development and implementation of freight distribution initiatives among stakeholders. Top-level managerial and 
organisational capacity is found unstructured and with limiting knowledge transfer, indicating that knowledge silos are an obvious vulnerability (Björklund and Gustafsson, 2015). Public procurement often takes a predominantly dyadic approach, whereas the sustainable transformational supply chain in a circular public procurement process, has to take a wider range of issues into account and extend along supply chains to create a new economy of transactions (Preuss, 2009).

Extending the dyadic perspective to include all related actors, requires a greater theoretical research focus devoted to understand how individual relational norms are managed and maintained over time (Oruezabala and Rico, 2012). Especially if management changes occur in the value chain network. Increased effectiveness occurs, if the strategic visionary framework, top-level transformational management, and technical aspects of the organisation embrace the opportunities that circular public procurement process provide (Sourani and Sohail, 2011).

\begin{tabular}{|c|c|}
\hline Sub-category: Agency and cross-departmental management & Authors \\
\hline $\begin{array}{l}\text { Psychological factors encompass barriers for individual factors, } \\
\text { organisational factors, internal and external adaptation processes towards } \\
\text { circularity } \\
\text { - Agency embeds enduring socio-economic structures - to avoid lock-in to } \\
\text { extant structures is training of senior management and mandatory circular } \\
\text { development targets suggested }\end{array}$ & Preuss and Walker (2011) \\
\hline - Challenges not only technological, but is influenced by human behaviour & Roman (2017) \\
\hline $\begin{array}{l}\text { - Change agents play a pivotal role in fostering the development of } \\
\text { individual engagement and innovative circular transformation }\end{array}$ & Grandia (2015); Roman (2017) \\
\hline $\begin{array}{l}\text { - Individual information exchange, collaboration and strategic knowledge } \\
\text { transfer paramount to effective processes }\end{array}$ & Björklund and Gustafsson (2015) \\
\hline $\begin{array}{l}\text { Silo-structures encompass possible hindrance to development of } \\
\text { knowledge and organisational capacity }\end{array}$ & Björklund and Gustafsson (2015) \\
\hline $\begin{array}{l}\text { - Extend dyadic perspective through devoted relational inclusion and } \\
\text { understanding of all relevant actors }\end{array}$ & $\begin{array}{l}\text { Oruezabala and Rico (2012); Preuss } \\
\text { (2009) }\end{array}$ \\
\hline
\end{tabular}

Table 5: Individual aspects of agency and cross-departmental management 


\subsubsection{Beliefs, awareness and individual guidance}

This section focuses on supplier selection in relation to supply chain management. To incorporate the full variety of possible circular public procurement criteria, there is a need to increase the commitment to transformational executive management and training for individual managers. In order to lower transaction costs practitioners should share best practices, consider how to incorporated circular public procurement criteria in contracts, and in particular they should reflect on how circular public procurement can support local economic development issues (Preuss and Walker, 2011).

One specific type of commitment for changing sustainable procurement behaviour is the affective commitment. Results show, that affective commitment to change acts as a mediator for an ecological sustainability approach, procedural justice, and a sustainable procurement vision (Grandi et al., 2015). The relevance appears to lie in how public organisations, that want to increase the sustainable behaviour of public procurers, can reach their goals. This requires not only ensuring a match between the policy and organisational strategic vision, but also increasing the affective commitment to change of individuals. If environmental criteria are used to select suppliers, the personal commitment is also important in terms of what motivates buyers. Public buyers are motivated by their belief in making a difference and the fact that the decision-making process is associated with recognition, availability, imitation and satisficing heuristics (Igarashi et al., 2017). Because behaviour positively mediates the relationship between affective commitment to change and knowledge, the individual procurer and the related behaviour are important in the application of circular public procurement in procurement and tender processes. Underestimating the influence of individual behaviour in the application of circular public procurement in procurement projects, could result in less circular procurement. Moreover, public authorities wishing to increase the application of compulsory and/or voluntary sustainable public purchasing in procurement projects, should focus on increasing the affective commitment to change and knowledge on available circular public procurement tools (Grandia, 2016).

Behavioural aspects play a pivotal role in an effective adoption of circular public procurement processes in public organisations, which implies that individual learning and training objectives must be in focus in order 
to implement and support an inherent belief in the benefits of circular public procurement practices. An argument supported by results showing, that local government procurement officials use life cycle costing criteria, if they are able to utilize such experiences within their organization (Sporrong and Bröchner, 2009). The existence of a general procurement policy prioritising sustainability and long-term thinking thus only provides a partial explanation for the use of circular public procurement criteria.

Another explanation lies in the fact, that local government procurement officials have individual preferences and opinions (experiences), which are mirrored in their procurement procedures (Sporrong and Bröchner, 2009). Therefore, it would be interesting and valuable to carry out comparative studies and examining the commitment to change and circular public procurement behaviour across different layers of government in various countries. Even though findings show the importance of an affective commitment to change and procedural justice, alignment with the vision and ecological sustainability approach plays an important role in determining circular public procurement behaviour, but are just some of the pieces of the puzzle. Variance in behaviour mostly remains unexplained and therefore calls for further research (Grandia et al., 2015). Additionally, the extent to which barriers (and enabling factors) differ between organisations that are experienced in conducting circular public procurement compared to those that less experienced, do also deserve further research (Preuss and Walker, 2011).

Consultancy procurement services show that only a minor amount of local government tenders includes sustainability related criteria in tender assessments. Even if the local governments have general policies for service procurement, the policies are not strictly followed. This indicates that distinguishing between circularity in procurement policies and circularity in the application of procurement policy, is perhaps relevant (Sporrong and Bröchner, 2009). Research on the interplay between environmental agendas, regulatory directives, organisational policies and strategies are also necessary. This goes together with an indepth examination of the individual skills among buyers of design and services in the public sector. Not to mention how these factors might influence the realisation of circular building projects. 
With a legal framework that supports adopting circular public procurement, it is argued that socioorganisational and human behaviour-related aspects, will determine whether the implementation and dissemination of circular public procurement takes place. Skills for assessing non-price criteria as part of technical and/or award quality criteria, such as those related to circular design, are needed to guide individual procurers in local government and other stakeholders. Researchers should therefore look into the effects of circular public procurement on both the environment and the real role of circular public procurement as stimuli for green innovation and in greening markets (Testa et al., 2016b). It is necessary with guidelines for circular public procurement, able to recognise and further strengthen the individual motivation of public buyers. Empowering procurers by providing additional information on circular issues, is an organisational leeway to more effectively influencing the purchasing process, providing the public procurer with additional authority, capacity and motivational energy (Igarashi et al., 2017).

Awareness and knowledge of circular public procurement techniques and procedures is apparently a strong driver for developing a supportive cognitive approach, while a lack of relevant techniques is a barrier for non-adopters. These factors appear to be even more important than the availability of economic resources and a flexible budget, which in general is perceived as crucial issues for public decision makers. Growing awareness and knowledge of what a circular public procurement oriented strategy means in the long run, could shift the approach of purchasers from being strictly cost oriented to life cycle costing oriented, which in turn may lead to a more effective management of public resources (Testa et al. 2016a; 2016b). Findings show how, even a minor amount of guidance, can positively influence attitudes towards the application of circular criteria. Despite the limited knowledge on the social aspects and life cycle costing, sustainable procurement is effective when proper guidance is provided (Erridge and Hennigan, 2012; De Giacomo et al., in press).

A high level of confidence obtained through improved knowledge, training and guidance creates operational individual effectiveness in circular public procurement processes. A clear definition of circular tenders and standard tools for circular public procurement monitoring, should enhance effectiveness among policymakers. One approach is to develop and disseminate best practices through training and workshops in 
as many parts of tendering organisations as possible. An establishing consensus life cycle assessment, that makes it able to compare products and services provides, gives public authorities a better monitoring procedures and best practices assessment tool (Testa et al., 2016b). Educating individuals in the utilisation of life cycle assessment and costing to support possible circular public procurement options, can enhance the affective commitment to change, and further help to develop an inherent belief that circular public procurement makes a difference. As a result, operational effectiveness improved through individual knowledge capability building focusing on general procurement, policy and strategies that prioritise circularity and long-term thinking, are thus essential aspects in terms of developing circular public procurement behaviour.

The degree of circular public procurement behaviour among procurers largely depends on personal beliefs and attitudes, which is why an examination of understudied variables that may influence behaviour, such as behaviour control, organisational stress, legal barriers and a lack of funding or knowledge is important (Grandia et al., 2015). Likewise, detailed research on behavioural aspects with the aim to understand how organisational mindsets influence the effectiveness of processes, would also be valuable. A better understanding of the cognitive limitations of purchasers and their perception of these limitations could gain more traction as a result of more in-depth research on how purchasers incorporate environmental criteria into traditional technical and award criteria (Igarashi et al., 2015).

\section{Sub-category: Beliefs, awareness and individual guidance}

\section{Authors}

- Affective commitment to change characterised by inherent belief in the

Grandia et al. (2015) benefits of circular public procurement

- Affective commitment to change, a mediator for an ecological Grandia et al. (2015) sustainability approach, procedural justice and circular public procurement vision

- Public buyers are motivated by the belief in making a difference through Igarashi et al. (2017) decision-making based on circular principles

- Individual procurer and related behaviour essential for application of circular public procurement in processes 


\begin{tabular}{|c|c|}
\hline $\begin{array}{l}\text { Individual learning and training on circular public procurement } \\
\text { opportunities to develop affective commitment }\end{array}$ & $\begin{array}{l}\text { Grandia et al. (2015); Sporrong and } \\
\text { Bröchner (2009) }\end{array}$ \\
\hline $\begin{array}{l}\text { Skills and guidance on circularity provides additional authority, capacity } \\
\text { and motivational energy by empowering procurers - a leeway to effective } \\
\text { processes }\end{array}$ & Igarashi et al. (2017) \\
\hline $\begin{array}{l}\text { Awareness and experience are more important to implementation of } \\
\text { circular public procurement and dissemination than economic resources }\end{array}$ & Sporrong and Bröchner (2009) \\
\hline $\begin{array}{l}\text { Awareness of long-term impact shifts approach from point of purchase } \\
\text { short-term cost to life-cycle costing orientation }\end{array}$ & Testa et al. (2016a; 2016b) \\
\hline $\begin{array}{l}\text { Little guidance positively influence attitudes towards application of } \\
\text { circular criteria's in tender processes }\end{array}$ & $\begin{array}{l}\text { Erridge and Hennigan (2012); De } \\
\text { Giacomo et al. (in press) }\end{array}$ \\
\hline $\begin{array}{l}\text { Dissemination of best practices through training, workshops and } \\
\text { monitoring enable effective support for developing implementation of } \\
\text { circular principles }\end{array}$ & $\begin{array}{l}\text { Erridge and Hennigan (2012); } \\
\text { Preuss and Walker (2011); Testa et } \\
\text { al. (2016b) }\end{array}$ \\
\hline
\end{tabular}

Table 6: Individual aspects of beliefs, awareness and individual guidance

\subsubsection{Conclusion on the individual behaviour and practices}

In summary, the individual behaviour and practice section describe the challenges related to agency, crossdepartmental management, beliefs, awareness and individual guidance. As highlighted, the challenges are of more than just a technical nature. They are also influenced by human agency embedded in enduring socioeconomic structures. Transforming the public purchase process from a linear approach focused on the lowest price as the only decision variable towards relying on the best relation between quality and price from a long-term perspective, requires a change in the intertwined behavioural practices and socio-economic structures.

The literature suggest that change agents play a pivotal role in developing individual engagement through knowledge dissemination and fostering collaboration. The exchange of information and the strategic transfer of knowledge are thus important aspects in transforming the behavioural practices of individuals.

Enlightened public buyers, often motivated by a trust, which they can make a difference and the actions they take are essential in an effort to adopt circular public procurement. An affective commitment to change, characterised by an inherent belief in the benefits of circular public procurement, act as a mediator for 
ecological sustainability, procedural justice and a circular public procurement oriented vision of change. In order to develop an affective commitment to change it requires the crucial step of establishing structures for individual learning and training concerning circular public procurement opportunities.

Information on circular attributes in general and on circular public procurement specifically, provides additional authority, capacity, and motivational energy, and only a small amount of guidance can lead to big impacts on transformational and individual development. Awareness and knowledge of circular public procurement principles have therefore a profound effect on individual behaviour and practices. Underlined by research showing that awareness and knowledge are even more important to the implementation and dissemination of circular public procurement than additional financial resources.

Knowledge about the long-term impacts of not pursuing circular public procurement can shift the public purchasing approach from a shortsighted focus on point of purchase cost, towards public procuring with a long-term life cycle costing perspective. One important factor to keep in mind in the transformation is, that knowledge silos represent a weak link in the dissemination of circular public procurement development, but can be mitigated by best practice training, workshops and monitoring. Understanding the power of relational norms and mandatory transformational development targets is essential too. To support the development of individual circular public procurement practices, public institutions must seek to create a work environment, where individuals understand and can appreciate the value of transforming public purchasing from a linear to a circular model.

\subsection{Operational tools}

The category operational tools comprise sub-categories: Process and prioritisation tools, Calculation and criteria setting tools, Standards, standardisation and legal aspects, and Supplier selection (Table 1). The first sub-category on Process and prioritisation tools (Table 7) provides insights on tools to support process decision-making. The second sub-category of Calculation and criteria setting tools (Table 8) exemplifies use of life-cycle assessments. Third sub-category on Standards, standardisation and legal aspects (Table 9) highlights importance of utilizing for example eco-labels and interpretation possibilities within the legal 
framework. Fourth sub-category Supplier selection (table 10) outlines perspectives to consider in selection processes. The articles included in this category have three mixed methods papers and the rest divides almost equally between qualitative and quantitative (Table 1).

\subsubsection{Process and prioritisation tools}

The circular public procurement operational processes encompass a five-step tool, which guides the implementation of systematic circular public procurement practices. The first is to develop internal policies in the context of circular economic factors to provide a specified direction for the purchasing unit. The second step is to set purchasing criteria based on the internal policies. The third step relates to internal procedures for assurance practices, which have to be applied in order to audit and evaluate supplier compliance with the purchasing criteria. The fourth step involves a focus on supplier relations management, for example by monitoring supplier practices, developing social targets, and applying measurable indicators. The fifth and last step involves building internal circular public procurement capacity that makes it possible to adjust and develop internal practices, that support and enhance supplier conformance (Leire and Mont, 2010).

A review identified phases of circular public procurement and outlining the process as a system of prerequirements, calls, selection, awarding and contracting. Findings show, that barriers and facilitators of various kinds affect all phases. Supporting elements are for example the overall circular public procurement strategies, life cycle costing, assessment tools, and eco-labels. Barriers comprise a lack of traceability, prioritisation and measurement tools (Cheng et al., 2018). A framework proposing inclusion of non-technical and technical specifications of product/service combinations to improve resource usage efficiency through recovery. The framework outlines how collaboration, as a link between circular public procurement and the development of more circular business models, can improve the contribution of suppliers and procurers to a circular economy. Further, highlighting the importance of socio-cultural specifications and physical and social proximity among stakeholders in the procurement processes (Witjes and Lozano, 2016). 
An example of a generic prioritisation tool is the analytic hierarchy process (Ahsan and Rahman, 2017), which is validated to serve as a support model for managers to understand the trade-offs between various environmental aspects (Oruezabala and Rico, 2012). Other examples of prioritisation tools are the Hurdle analysis (Günther and Scheibe, 2006) and the relevance-potential-steerability tool (Parikka-Alhola, 2008).

The analytic hierarchy process is a multi-criteria decision-making model, that uses quantitative integer priority scores on a 1-9 scale to prioritise weights. Participants are usually a small sample of senior executives, knowledgeable about the issue under study (Ahsan and Rahman, 2017). Another analytical tool is the Hurdle analysis, which is an organisational self-evaluation tool, able to help local authorities to identify, analyse, and overcome hurdles to circular public procurement. The objective of this tool is to identify obstacles to circular public procurement and acknowledges that procurement is a specialised decisionmaking process comprising demand management, market research, tender/award procedures and the procurement process as involving actors who can potentially serve as both a resource and a hindrance (Günther and Scheibe, 2006). The hurdles are analysed in an online questionnaire based on contingency theory, which states that successful decision-making differs from organisation to organisation, because of its situation, strategies, size, and employees. Another framework incorporates structured macro level categories and micro level challenge. The operational properties in the Hurdle analysis tool and the analytic hierarchy process contain sorting and prioritisation tools for public decision makers and procurers to enhance circular public procurement by delivering a point of departure for implementing and further mapping out obstacles.

The relevance-potential-steerability tool measures and evaluates relevance, potential and steerability to determine whether improvements in environmental criteria, can be utilised through certain eco-label standards or design criteria (Parikka-Alhola 2008). Systematically presented green criteria, specifically, ecodesign strategies covering product-related criteria, corporate level environmental performance, recycling facilities for low-impact materials and optimisation of lifetime and waste management, provide a strong signal to manufactures. Eco-design strategies address the production and end-of-life phases, where a major environmental impact exists in for example office furniture production supporting circular public procurement (Parikka-Alhola, 2008). Research on the applicability of less complex tools for evaluation 
processes is also called for, as tools that are too complex might become an obstacle to incorporating circular public procurement in operations. Research into this area should be accompanied by measuring the effects of structured use of the above prioritisation tools, along with the structured use of life cycle assessment and costing, in relation to the stimulation of eco-innovation and operations in general.

A list of prioritisation recommendations for local authorities to enhance circular economic development when procuring computers, is developed as an example of how to supplement the generic prioritisation tools outlined above. Their first recommendation is to use computers as long as possible and then resell them to manufacturers. The second is to conduct proper market studies and to speak with suppliers before establishing suitable criteria that can prolong the lifespan. The third recommendation is to determine whether procuring remanufactured computers is an option for some municipal programmes or units, for example for educational activities in schools, where the newest processing power is less important. As the fourth, they recommend looking at potential options for rewarding suppliers, that have recycled content in new devices. The fifth is to ensure that suppliers provide evidence of compliance with contract circular public procurement criteria after closing the contractual agreements (Crafoord, Dalhammar and Milios, 2018).

\begin{tabular}{|c|c|}
\hline Sub-category: Process and prioritisation tools & Authors \\
\hline $\begin{array}{l}\text { - Five-step process is developed to guide systematic implementation of } \\
\text { circular public procurement practices }\end{array}$ & Leire and Mont (2010) \\
\hline $\begin{array}{l}\text { - Phases of pre-requirements, calls, selection, awarding and contracting is } \\
\text { all identified as having barriers and facilitators }\end{array}$ & Cheng et al. (2018) \\
\hline $\begin{array}{l}\text { - Process enablers: overall strategies for circularity, ecolabels, life cycle } \\
\text { assessment and costing }\end{array}$ & Cheng et al. (2018) \\
\hline - Process barriers: lack of traceability, prioritisation and measurement tools & Cheng et al. (2018) \\
\hline $\begin{array}{l}\text { - Collaboration and dialogue with the market is considered a lever to } \\
\text { develop more circular business models through the pro-active use of } \\
\text { technical and non-technical specification in minimum demands }\end{array}$ & Witjes and Lozano (2016) \\
\hline $\begin{array}{l}\text { Analytic hierarchy process tool developed as a multi-criteria decision- } \\
\text { making tool to support prioritisation of weighting in tender proposals }\end{array}$ & Ahsan and Rahmann (2017) \\
\hline $\begin{array}{l}\text { - Hurdle analysis tool developed to identify obstacles when using circular } \\
\text { principles in public procurement processes }\end{array}$ & Günther and Scheibe (2006) \\
\hline
\end{tabular}




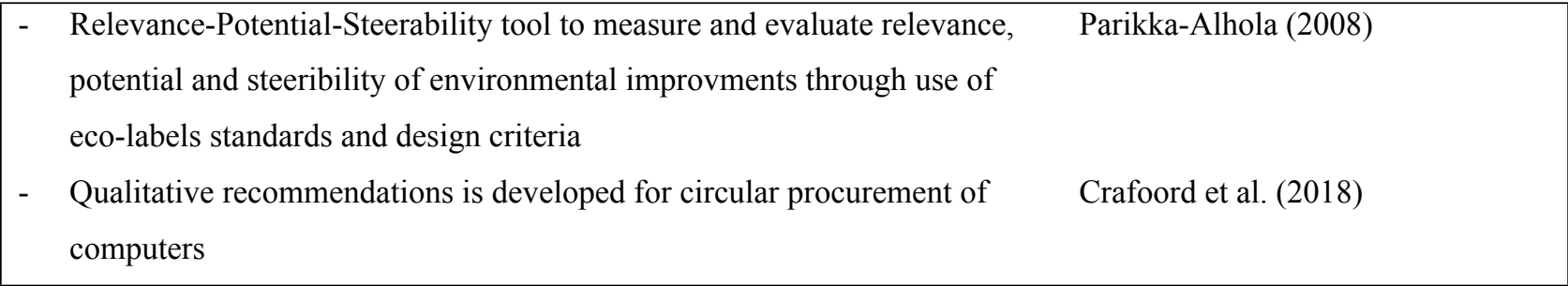

Table 7. Findings on operational tools related to process and prioritisation tools

\subsubsection{Carbon emissions as a criteria setting and evaluation tool}

An ideal circular public procurement is free of carbon emissions in relation to use of energy (Pearce and Turner, 1990). Findings show that public procurement do have the potential to promote such criteria not only for circular economic principles but also in general (Alhola et al., 2018). Measuring the impacts of embedded carbon emissions from purchased products, services or works is outlined as a helpful tool in setting up selection criteria. Consider the evaluation of the environmental impact of one part of a building, such as windows. Research shows that transport and primary energy consumption in the production phase of windows, are significant sources of emissions. The life cycle assessment did not provide procurers with a set of criteria in the tender process, but did identify the main impact and critical processes to allow a discussion of circular public procurement with manufacturers (Tarantini et al., 2011).

Another study on catering services in schools, focused on three main phases in the supply chain to assess the climate change potential in production, provision and distribution of the services. The results showed that 61$70 \%$ of the greenhouse gases are emitted in the production phase, $6-11 \%$ from the provision phase and $24-$ $28 \%$ in the urban distribution phase. The life cycle assessment also shows, that a shift from conventional to organic production would result in an average reduction in total greenhouse gas emission, which was even higher if integrated production replaced organic production (Cerutti et al., 2016).

The aforementioned results point to a general need to evaluate the various phases of production, distribution logistics and after use, as well as the impact of different operational production scenarios to access embedded emissions in purchased products, services and work. Another study calculated and compared the carbon footprint in a project for two consecutive years, and showed that inclusion of carbon footprint in circular public procurement acts as a stimulus for eco-innovation (Alvarez and Rubio, 2015). This is in line with the 
carbon footprint calculations presented in the computer maintenance, window and catering studies. A pilot study on road construction showed that the highest environmental impact, is the combustion of fossil fuels in the transport of materials. Although the study has some limitations and drawbacks, it provides valuable insights, and it unambiguously indicates that this type of selection criteria will be a part of future tenders (Anthonissen et al., 2015). Life cycle assessment and other carbon-emission calculation tools thus provide a process platform, that can be utilised to create market dialogue in relation to the impact of carbon emissions, which further can be used in the evaluation of possible market-ready or innovative solutions.

The above examples show, how utilization of available emission calculations and measurement tools create awareness among suppliers of future trajectories in public purchasing requirements. The simple carbon footprint calculations also highlight how assessment of environmental impact is limited and calls for more detailed life cycle assessment as part of the public procurement assessment process. Some of the drawbacks are, that life cycle assessments are time-consuming and must be calculated at the individual product/process level, which increases the transaction cost, and put further pressure on the monetary gains derived from circular public procurement.

\begin{tabular}{|lll|}
\hline \multicolumn{1}{|c|}{$\begin{array}{l}\text { Sub-category: Carbon emissions as criteria setting and } \\
\text { evaluation tool }\end{array}$} & \multicolumn{1}{c|}{\begin{tabular}{c} 
Authors \\
\multicolumn{1}{|c|}{$\begin{array}{l}\text { Life cycle assessment of window for discussion on manufacturing } \\
\text { emissions in market dialogue - emissions relating primarily to production } \\
\text { and logistics }\end{array}$}
\end{tabular}} \\
- $\begin{array}{l}\text { Life cycle assessment of catering service schools describe } \mathrm{CO}_{2} \text { emissions } \\
\text { at different logistical phases - impact relate to production and logistics }\end{array}$ & Cerutti et al. (2016) \\
- $\begin{array}{l}\text { Inclusion of carbon emissions in evaluation procedures act as stimulus for } \\
\text { eco-innovation }\end{array}$ & Alvarez and Rubio (2015) \\
- $\begin{array}{l}\text { Life cycle assessment or other simple calculus tools can provide a } \\
\text { platform for market dialogue and evaluation of market innovations }\end{array}$ & Anthonissen et al. (2015) \\
\hline
\end{tabular}

Table 8. Findings on operational tools related to carbon emissions and criteria setting tools 


\subsubsection{Standards, standardisation and legal aspects}

Standards and standardisation when implementing circular public procurement in purchasing can drive market development. An operational innovation space framework for public procurers allows better visualisation of products and services when making tender design and purchasing decisions. An innovation space suggesting that standards intended as knockout criteria should be presented as technical requirements, whereas standards that stimulate voluntary performance of potential suppliers, should be presented in tenders as reward criteria (Rainville, 2017).

The operational space for innovation with standards and standardisation is divided up in relation to the level of complexity of the purchase. The first and most complex level is pre-commercial procurement that covers products or services with characteristics that surpass those currently on the market. The benefits of precommercial procurement are based on the market conditions phase, which enhances attempts to introduce radical innovation and mostly related to risk reduction, as risk is shared through the partnership process between purchaser and supplier. The second level involves public-private-innovation partnerships related to incremental innovations through integration, customisation or the adaptation of existing solutions to meet user needs. Eco-labelled and eco-designed products represent another level, and they are characterised by off-the-shelf purchasing (Rainville, 2017). If a need cannot be covered by off-the-shelf products and services, are pre-purchase tools available to enhance circular public procurement in procurement processes, while simultaneously reducing the inherent risk in complex processes. Recommendations on changing the service innovation process to comply with circular public procurement attributes, serve to supplement the innovation space framework. The first recommendation is that environmental and social competences in the purchasing team should be improved and broadened. Secondly, robust short and long-term objectives should be defined and agreed upon in the procurement department. Thirdly, focus on the products, per se, should change to a focus on the function being provided (Bratt et al., 2013).

Inertia or a lack of pro-active application of the opportunities in implementing circular public procurement criteria in purchasing processes, is underlined when examining public tender and contract documents. Research shows that environmental aspects are not considered of particular importance, which means the 
way they are formulated, is often given scant attention. Although public procurement frequently seeks to consider environmental aspects, and despite the presence of innovative practices, procurement processes still tend to favour past practices in an effort to avoid potential legal conflicts (Palmujoki et al., 2010). A content analysis of public construction tenders also indicates a limited use of green criteria, criteria that mainly focus on energy consumption and recycled materials. This is a relevant insight, because omitting other environmental issues that influence the building process for example, will lead to a situation where the full impact of buildings is undervalued (Testa et al., 2016b). In other words, a tender and an evaluation process that does not include the impact and effects of the production process, is too narrow and influences the effectiveness of adopting circular public procurement principles. Another important area for further study is whether the low weight (mostly) assigned to environmental criteria is related to the uncertainty about how to compare environmental performance with economic performance (Igarashi et al., 2015) as part of optimising contractual agreements.

Despite existing circular public procurement legal options for integrating environmental protection requirements, various issues limit the effective application of circular public procurement processes. These issues prevent public authorities from profiting from the full potential of circular public procurement. Transferring the burden of proof to the contracting authority in justifying its decision not to implement circular public procurement, could lead to a more effective application of circular public procurement criteria. Public authorities forced to accomplish an exhaustive market-based analysis to make informed decisions may mitigate ignorance on relevant circular public procurement criteria (Zvaigzdiniene and Rudauskiene, 2012) and represents an additional possible way of reducing any inertia in developing circular public procurement processes.

Public authorities are therefore encouraged to use tender templates to standardise the legal/normative aspects of the tender, as well as to apply life cycle assessment and costing, in order to gain an overview of carbons emissions and the full cost a product generates during its lifespan, not just in relation to upfront purchasing cost (Testa et al., 2016b). This approach provides a more in-depth overview of the impact of public purchases compared to the simple model, that solely relies on the lowest purchase price. The most 
economically advantageous tender, defined as the best relation between quality and price in a life cycle perspective (Directive 2014/24/EU; ISO 20400, 2017), gives the contracting authorities an opportunity to obtain the best value for money, while prohibiting discriminatory purchasing policies. Value for money in a circular public procurement context, is a combination of quality, quantity, risk, timeliness and cost for the local authorities based on the entire lifespan of a product (Ahsan and Rahman, 2017).

A higher level of awareness about existing tools for supporting the adoption of circular public procurement could increase the adoption of circular public procurement practices and minimise the purchase of products and services solely based on the lowest price at point of purchase, which is seldom consistent with the circular economy. Other characteristics that must be included are for example, quality, technical merits, aesthetics, functional features, operational costs, cost-effectiveness, after-sales service and technical assistance, delivery date and period of completion. The objectivity of the award remains important from a legal perspective, which means it is linked to the subject matter of the public contract (Palmujoki et al., 2010). A minor level of awareness about the various circular public procurement options available is of high relevance since procurers have an obligation towards the taxpayers, as they are spending their money. When the level of awareness is low, the perceived risk of using unfamiliar tools will overrule the perceived gains, because the decision maker is ultimately accountable for the actions. In other words, a range of opportunities are available for consideration to purchasing entities and individuals to enhance the best relation between quality and price beyond the model, that uses the simple lowest price at point of purchase. An awareness and knowledge of these opportunities are thus crucial to the implementation and effectiveness of the circular public procurement process.

\begin{tabular}{|lll|}
\hline \multicolumn{1}{|c|}{$\begin{array}{l}\text { Sub-category: Standards, standardisation } \\
\text { and legal aspects }\end{array}$} & \multicolumn{1}{c|}{ Authors } \\
\hline - & $\begin{array}{l}\text { A developed operational space for innovation can guide complex circular } \\
\text { public procurement and reduce perceived risk }\end{array}$ & Rainville (2017) \\
$-\begin{array}{l}\text { Circular public procurement aspects are either not considered or given } \\
\text { special attention in tenders and contracts - indicating that public }\end{array}$ & Palmujoki et al. (2017) \\
\hline
\end{tabular}


procurement processes tends to favour past practices to avoid legal

problems per automation

- Evaluation of impacts must include the impact of production, transport

Testa et al. (2016b)

logistics and after use - to avoid situations of under estimating embedded emissions impact

- Ignorance towards including relevant circular public procurement criteria are mitigated through mandatory market analysis and justification of noncompliance

- Most economically advantageous tenders are defined as the best relationship between price and quality, i.e. the best value for public money is a combination of quality, quantity, risk, timeliness and cost from a lifecycle perspective

- Award criteria must be linked to the subject matter of a contract to comply with legal requirements when awarding contracts

Table 9. Findings on operational tools related to standardisation and legal aspects

\subsubsection{Supplier selection}

This section examines the anatomy of supplier selection in-depth in light of the increased complexity, that ensues when circular quality variables are included in criteria setting and the selection process. Findings indicate that a variety of environmental criteria are used at the various stages involved in the selection process, and that supplier decision-making applies the following four main strategies to simplify processes of supplier selection: ignore, incorporate, insist and integrate (Igarashi et al., 2015).

The first strategy (ignore) is the absence of environmental criteria or requirements in tenders. The second strategy (incorporate) includes environmental performance under existing criteria and requirements, which means the strategy is perceived as involving making minor, incremental adjustments to existing standard operating procedures or no change at all. The third (insist) comprises supplier selection processes that include environmental criteria on specifications and qualification processes as mandatory requirements to avoid trade-offs. The fourth and last strategy (integrate) expands the use of environmental criteria from solely specifications and qualification, to also include the award phase of the circular public procurement process. This also covers any trade-offs between environmental performance and other criteria, such as price 
and quality, by using weights in the award phase, even though environmental criteria were used less often than price and quality (Igarashi et al., 2015).

Environmental criteria still appear to make little influence concerning the final decision in supplier selection based on the weights they were assigned. Previous studies indicate that this is caused by a lack of training and competences among public procurers on sustainability and environmental issues (Igarashi et al., 2015). If public procurers take a pro-active, strategic position toward including circular public procurement, they should as a minimum, be provided with the sufficient and suitable knowledge and training on the circular public procurement tools available to obtain skills, able to enhance their confidence and ability to conduct the circular public procurement process effectively.

Analyse on complexity in handling supplier selection through the impact of circular public procurement on supplier management found that obstacles are internal (opposition from other services) and external (budget constraints, poor supplier expertise). Further, that beyond formal contracts, relational norms are of strategic importance in terms of structuring efficient relationships over time. Purchasing managers rely on key suppliers with shared values and expectations regarding sustainability in the selection process (Oruezabala and Rico, 2012). Thus, more than just the anatomy of supplier selection is of unmistakeable strategic importance. Relational shared values with suppliers, beyond formal contracts, also play a role in managing effective circular public procurement processes. A competitive dialogue procedure is a procurement procedure tool, that allows the contracting authority to establish relationships before the actual bidding phase, by communicating with shortlisted contractors regarding official requirements before and during the tender process. For practitioners, the fact that procurement procedures require a high degree of flexibility and dialogue between public sector clients and bidding private contractors is an important aspect of a complex tender process. Especially when projects are large and complex.

Pre-commercial procedures, public-private innovation and competitive dialogue procedures provide legal tools able to facilitate the supplier dialogue and selection process of large complex projects in a nondiscriminatory way. The use of a competitive dialogue procedure should be restricted to particularly complex 
contracts, where the technical complexity consists of risks, that arise from the technical and physical features of the project. Legal and financial complexity are often associated with risk and therefore exemplify what most often justifies recourse to a competitive dialogue procedure (Uttam and Roos, 2015). Thus, the use of a competitive dialogue procedure can enhance the decision maker's confidence, by mitigating the perceived risk through dialogue, while the process simultaneously contains the opportunity to increase effectiveness further by reducing the cost from a life cycle costing perspective. Specifically, do findings highlight, that market dialogue in general between procurers and suppliers are a necessity in future development of circular public procurement (Alhola et al., 2018).

\begin{tabular}{|lll|}
\hline \multicolumn{2}{|c|}{ Sub-category: Supplier selection } & \multicolumn{1}{c|}{ Authors } \\
\hline - $\begin{array}{l}\text { Four proposed strategies to simplify supplier selection: ignore, } \\
\text { incorporate, insist and integrate }\end{array}$ & Igarashi et al. (2015) \\
- $\begin{array}{l}\text { Environmental criteria seems to have little influence concerning the final } \\
\text { supplier selection decision looking at weighing allocated }\end{array}$ & Igarashi et al. (2015) \\
- $\begin{array}{l}\text { Purchasing managers rely on key suppliers with shared values and } \\
\text { expectations regarding circularity - }\end{array}$ & Oruezabala and Rico (2012) \\
- $\begin{array}{l}\text { Supplier management meets internal and external obstacles - relational } \\
\text { norms are therefore of strategic importance in effective long-term }\end{array}$ & Oruezabala and Rico (2012) \\
structures & \\
- Competitive dialogue procedures is a procurement process legal tool that & Uttam and Roos (2015) \\
allow contracting authority to establish relations with short listed bidders & \\
before and during the tender process & \\
Competitive dialogue procedures should be restricted to complex & Uttam and Roos (2015) \\
contracts and tender processes & Alhola et al. (2018) \\
\hline $\begin{array}{l}\text { Market dialogue is essential in future development of circular public } \\
\text { procurement }\end{array}$ & \\
\hline
\end{tabular}

Table 10. Findings on operational tools related to supplier selection

\subsubsection{Conclusion on the operational tools}

The first sub-category under the umbrella of operational tools outlined that circular public procurement is a purchasing system based on pre-requirements, calls for tender, selection, awarding, and contracting.

However, these attributes also play a role in linear public purchasing. The difference lies in taking a circular 
public procurement approach to five basic, consecutive steps, which involves: developing internal policies, setting purchasing criteria, creating internal procedures for assurance practices, establishing supplier relations management, and building internal circular public procurement capacity.

Process and decision outcomes are evaluated by using life cycle assessment, costing, eco-labels, and other strategic circular economic tools in general. However, lack of training, linear economic prioritisation and a failure to take measurements able to shed light on possible outcomes, will hamper effective processes. Tools proposed for prioritising operational tasks are the analytic hierarchy process, the Hurdle analysis, and the relevance, potential and steerability tool. In the case, involving the purchase of computers a set of qualitative recommendations can provide the procurer with guidelines to navigate among various possibilities available in the process.

The second operational area involved the use of life cycle assessment to enable criteria setting and as an evaluation tool to help procurers understand the amount of emissions, produced and embedded. This is associated with a specific purchase. Including carbon emission calculations as evaluation criteria in tenders act as market communication and stimulate eco-innovation among suppliers. Life cycle assessment research clearly show, that the emissions from manufacturing windows and from a catering service for schools relates to the production and logistics phase. Further, it is also clear that the environmental impact of road construction is due to the combustion of fossil fuels in the transport of materials.

The third operational area relates to the use of standards, standardisation, and legal aspects, which can drive market development in a preferred direction. Unfortunately, evidence shows that circular public procurement principles are either not considered in tender processes or given any special attention in tenders and contracts, because past practices are favoured to avoid legal conflicts. Public procurers are therefore encouraged to use a defined, operational innovation space to reduce risk when innovating complex circular public procurement processes or eco-labels if products are off-the-shelf solutions. Furthermore, ignorance towards including relevant circular public procurement criteria, decrease with the use of a mandatory market analysis and the justification of choices in the event of non-compliance with possibly useful circular public 
procurement criteria. Award criteria must be linked to the contract's subject matter and value for money is defined as a combination of quality, quantity, risk, timeliness and cost from a life cycle perspective. The inclusion of all the parameters of value for money, enhance the most economically advantageous tenders, defined as the best relation between price and quality from a long-term perspective.

The fourth and final area of operational tools relates to supplier selection issues, and describes the four specific strategies named ignore, incorporate, insist, and integrate. Supplier management meets both internal and external obstacles and pro-active strategic positioning through supplier selection requires skills. Environmental criteria are an example of this kind of decision tool; however, the empirical evidence indicates, that environmental criteria have little influence on supplier selection. Similar findings relate to norms of strategic importance in effective long-term structures, which relates back to the importance of individuals understanding of how to allow relational norms to flourish. Purchasing managers thus need key suppliers with shared values and expectations to enhance the quality of long-term relationships. In a specific tender process, where the subject matter is of an extra complex nature, a competitive dialogue procedure allows the creation of relationships with possible suppliers, which is an aspect that can mitigate perceived risk among procurement professionals and embrace innovation in relation to the preferred solution.

\section{Conclusion}

The creation of pre-conditions for more and better circular public procurement practices is considered an effective tool to promote more environmentally, socially and ethically friendly modes of production and consumption than business as usual. The overall conclusion in this review is that literature primarily covers three areas with regard to circular public procurement: organisational aspects, individual behaviour and operational tools.

The review further showed, that the level of awareness and knowledge of existing tools for supporting the adoption of circular public procurement, is one of the most important factors in decision making on technical specification and award criteria. When creating awareness and knowledge base connected to organisational 
strategies, the perceived risk will decrease in the process of entering a new domain, and create a foundation for a better exploitation of the opportunities the circular public procurement practices offers.

Another salient barrier to implementing circular public procurement is the financial pressure related to the perception that products and services based on circular principles involves higher prices, which is incompatible with the budget constraints practitioners in public organisations experience. A higher level of awareness and knowledge for example, using different operational tools to enhance the processual skills of the procurer, increase the adoption of circular public procurement practices based on life-cycle costing. This results in a decrease in the purchase of products, services and work at the lowest price at point of purchase, which is not necessarily consistent with circular economic principles. Support from engaged top-level management acts as a strong facilitator, underlining the importance of a clear mandate and direction as important in facilitating the adoption of circular public procurement. Implementing strategies and commitments that contain circular policies is considered crucial in leveraging the circular public procurement process. The importance of strategic political ambitions mandating top management creating continuity, is therefore highlighted as essential in the effort to conduct effective circular public procurement.

Effective circular public procurement processes depend upon the presence of actors with an inherent belief in the benefits of circular public procurement practices, supported by organisational structures, a high level of perceived procedural justice and a strategic vision that supports meeting the needs of the future without compromising the needs of the present through circularity. The individual procurer's beliefs and values are of high relevance in the application of effective circular public procurement processes. Operational effectiveness is supported by a high level of confidence, obtained through activities connected to improved knowledge, training and capacity building based on values and beliefs that prioritise circularity and longterm thinking.

As value for money is not simply lowest purchase price, but an optimum combination of quality, quantity, risk, timeliness and cost for the public authority on a life cycle basis, then the application of life-cycle assessment and costing found do get high relevance when considering implementation of future circular 
public procurement processes. A combination of eco-labels, standards, life-cycle assessment and costing create transparency and supports best practice circular public procurement processes, specifically when implemented as knockout criteria in technical requirements or as award criteria to stimulate voluntary performance improvements. If no off-the-shelf standard product or service is available to the procurement unit in more complex tender procedures, pre-commercial procedures, public-private innovation and/or a competitive dialogue procedure can be of special help in circular public procurement processes.

A systematic use of circular criteria, either in a standardised or ad-hoc tender process, signals the trajectories of the future of public procurement and suppliers. Using a range of tools and opportunities supported by a legislative framework to enhance the best relation between quality and price, beyond the simple lowest price at point of purchase, can thus increase confidence and decrease the perception of risk among procurers, and thereby increasing the effectiveness of circular public procurement processes.

\section{Limitations and further research}

Limitations in relation to this literature review is first of all method used being a narrative literature review compared to a systematic. Where a systematic review would be subject to predefined guidelines and established through expert pre-filtered evidence presenting the methodology strongest empirical data in an area (Schlosser, 2006), there is no acknowledged guidelines for narrative review (Ferrari, 2015). However, the narrative literature review can be improved by borrowing from the systematic review methodologies (Ferrari, 2015), with the objective to synthesize results from multiple original studies by limiting systematic errors or bias (Cook et al., 1997). By designing a research protocol for funnelling of extant literature to achieve 1) a broad and comprehensive overview of previous findings on circular public procurement; 2) robust, reliable and valid research findings; and 3) a geographic area limited to Organisation for Economic Co-operation and Development countries due to their cultural and contextual similarities. The authors find, that the literature review embrace the rigor of a systematic review and the outlined coding method is possible biases mitigated. 
Further, it is considered a limitation to the study, that available literature and empirical evidence on public procurement processes designed to enhance circularity is limited. However, the argument spelled out by Alhola and colleagues (2018) on the similarities of green, sustainable and circular public procurement provide a legitimate foundation for outlining the collected knowledge under the umbrella of one concept. Yet, more evidence empirically derived from public procurement processes with a focus on inclusion of circular principles specifically in future research, will undoubtedly create better insights to dynamics in processes and effective impact. A least limitation to the literature review is that national interpretations of the legal rules could have more diverse aspects than the two studies covering UK and Italy illuminate. However, with the rules and regulations at least in Europe being based on the same legal framework, a certain alignment can be assumed and possible contextual differences would be mitigated in the future. Yet, this area is relevant for further studies, especially differences between the American countries and European countries within the OECD and further how public procurement based on circular principles could benefit emerging economies.

Besides the recommendation for future research in the paragraph above and the outlined recommendations for further research by authors included in the review that is presented in the paper, there are a few more aspects that need attention. The role of market dialogue needs to be understood to a higher degree in diverse contextual settings, with product and service value offerings of different variation. Market dialogue is highlighted as essential in purchase involving complex processes and innovative products. However, purchase relates to complexity in relation to the procurer's professionalism and product knowledge and further, affective commitment to change have an effect on perceived complexity of purchasing processes. Additionally this review has provided insights related to centralized data driven procurement systems, inclusion of ISO 20400 guidance on public procurement or other guidance tools, and the role of national supportive structures as for example the Dutch 'Green Deal' or the Danish ' Rejsehold for Grønne Indkøb' lack empirical investigation. 


\section{Acknowledgements}

As a part of a PhD programme, this research is financially supported by the Technical and Environmental Department of the City of Copenhagen. Great thanks to Mette Skovgaard, senior advisor, City of Copenhagen, and Nancy Aaen, language consultant, for proofreading and commenting on the final manuscript. The authors and the two proof readers did not have any commercial interest in the results and findings. Only the authors participated in the literature collection, analysis, interpretation and writing of this state-of-the-art review.

\section{References}

Ahsan, K. and Rahman, S., 2017. Green public procurement implementation challenges in Australian public health sector. J. Clean. Prod. 152, 181-197. https://doi.org/10.1016/j.jclepro.2017.03.055.

Aldenius, M. and Khan, J., 2017. Strategic use of green public procurement in the bus sector: Challenges and opportunities. J. Clean. Prod. 164, 250-257. https://doi.org/10.1016/j.jclepro.2017.06.196.

Alhola, K., Ryding, S.-O., Salmenperä, H. and Busch, N.J. 2018. Exploiting the Potential of Public Procurement, J. Ind. Ecol., Vol. 23, (1), 96-109. DOI: 10.1111/jiec.12770

Alvarez, S. and Rubio, A., 2015. Carbon footprint in Green Public Procurement: A case study in the service sector. J. Clean. Prod. 93, 159-166. https://doi.org/10.1016/j.jclepro.2015.01.048.

Amann, M., Roehrich, J.K., Essig, M., and Harland, C., 2014. Driving sustainable supply chain management in the public sector: The importance of public procurement in the European Union. Supply Chain Manag. 19, (3), 351-366. https://doi.org/10.1108/SCM-12-2013-0447.

Anthonissen, J., Troyen, D. V., Braet, J., and Van den bergh, W., 2015. Using carbon dioxide emissions as a criterion to award road construction projects: A pilot case in Flanders. J. Clean. Prod. 102, 96-102. https://doi.org/10.1016/j.jclepro.2015.04.020. 
Björklund, M. and Gustafsson, S., 2015. Toward sustainability with the coordinated freight distribution of municipal goods. J. Clean. Prod. 98, 194-204. https://doi.org/10.1016/j.jclepro.2014.10.043.

Brammer, S. and Walker, H., 2011. Sustainable procurement in the public sector: An international comparative study. Int. J. Oper. Prod. Man. 31 (4), 452-476. https://doi.org/10.1108/01443571111119551.

Bratt, C., Hallstedt, S., Robèrt, K.H., Brormand, G., and Oldmark, J., 2013. Assessment of criteria development for public procurement from a strategic sustainability perspective. J. Clean. Prod. 52, 309-316. https://doi.org/10.1016/j.jclepro.2013.02.007.

Cerutti, A.K., Contu, S., Ardente, F., Donno, D., and Beccaro, G.L., 2016. Carbon footprint in green public procurement: Policy evaluation from a case study in the food sector. Food Policy, 58, 82-93. https://doi.org/10.1016/j.foodpol.2015.12.001.

Cheng, W., Appolloni, A., D'Amato, A,. and Zhu, Q., 2018. Green Public Procurement, missing concepts and future trends - A critical review. J. Clean. Prod. 176, 770-784. https://doi.org/10.1016/j.jclepro.2017.12.027.

Chiarini, A., Opoku, A. and Vagnoni, E., 2017. Public healthcare practices and criteria for a sustainable procurement: A comparative study between UK and Italy. J. Clean. Prod. 162, 391-399. https://doi.org/10.1016/j.jclepro.2017.06.027.

Coggburn, J.D., 2004. Achieving managerial values through green procurement? Public Perform. Manag. 28 (2), 236-258. https://www.jstor.org/stable/3381063.

Cook, D.J., Mulrow, C.D. and Haynes, R.B. 1997. Synthesis of best evidence for clinical decisions, An. Int. Med., Vol. 126, Issue 5, pp. 376-280.

Commission to the European Parliament, the Council, the European Economic and Social Committee and the Committee of the Regions, 2015. Closing the loop - An EU action plan for the Circular Economy. Available at: https://www.eea.europa.eu/policy-documents/com-2015-0614-final (Accessed: 6/6 2018) 
Corbin, J. and Strauss, A., 1990. Grounded theory research: Procedures, canons and evaluative criteria. Z. Soziol. 19 (6), 418-427. DOI :10.1007/BF00988593.

Crafoord, K., Dalhammar, C., and Milios, L., 2018. The use of public procurement to incentivize longer lifetime and remanufacturing of computers. Procedia CIRP. 73, 137-141.

https://doi.org/10.1016/j.procir.2018.03.316

De Giacomo, M.R., Testa, F., Iraldo, F., and Formentini, M., 2018. Does green public procurement lead to life cycle costing (LCC) adoption? J. Purch. Supply Manag. In Press. https://doi.org/10.1016/i.pursup.2018.05.001.

Ellen MacArthur Foundation, 2013. Towards the circular economy Vol. 1: An economic and business rationale for an accelerated transition. Available at: https://www.ellenmacarthurfoundation.org/publications/towards-the-circular-economy-vol-1-an-economicand-business-rationale-for-an-accelerated-transition (Accessed: 3/6 2018)

Erridge, A. and Hennigan, S., 2012. Sustainable procurement in health and social care in Northern Ireland. Public Money Manage. 32 (5), 363-370. https://doi.org/10.1080/09540962.2012.703422.

EU Commission, 2016. What is Green Public Procurement? Available at: http://ec.europa.eu/environment/gpp/what_en.htm, (Accessed: 15/1 2018).

EU Commission, 2017. Public procurement for a circular economy: Good practice and guidance. Available at: http://ec.europa.eu/environment/gpp/pdf/Public procurement circular_economy brochure.pdf (Accessed: $5 / 62018)$

The European Parliament and the Council of the European Union, 2014. Directive 2014/24/EU of the European Parliament and of the Council of 26 February 2014 on public procurement and repealing Directive 2004/18/EC. Official Journal of the European Union, L 94/65. Available at: https://eur-lex.europa.eu/legalcontent/en/TXT/?uri=CELEX\%3A32014L0024\#document1 (Accessed: 30/5 2018). 
Ferrari, R. 2015. Writing narrative style literature reviews, Medical Writing, Vol. 24, No. 4, pp. 230-235.

Geissdoerfer, M., Paulo, S., Bocken, N.M.P., and Hultink, E.J, 2017. The circular economy - A new sustainability paradigm? J. Clean. Prod. 143, 757-768. https://doi.org/10.1016/j.jclepro.2016.12.048.

Grandia, J., 2015. The role of change agents in sustainable public procurement project. Public Money Manage. 35 (2), 119-126. https://doi.org/10.1080/09540962.2015.1007706.

Grandia, J., 2016. Finding the missing link: Examining the mediating role of sustainable public procurement behavior. J. Clean. Prod. 124, 183-190. https://doi.org/10.1016/j.jclepro.2016.02.102.

Grandia, J., Steijn, B., and Kuipers, B., 2015. It is not easy being green: Increasing sustainable public procurement behavior. Inno. Europ. J. Soc. Sci. 28 (3), 243-260.

https://doi.org/10.1080/13511610.2015.1024639.

Green Public Procurement and the EU Action Plan for the Circular Economy, 2017a. Policy Department A: Economic and Scientific Policy, Requested by European Parliament's Committee on Environment, Public Health and Food Safety.

Guenther, E., Hueske, A-K., Stechemesser, K., and Buscher, L., 2013. The 'why not' perspective of green purchasing: A multilevel case study analysis. J. Change Manag. 13 (4), 407-423.

https://doi.org/10.1080/14697017.2013.851950.

Günther, E. and Scheibe, L., 2006. The hurdle analysis: A self-evaluation tool for municipalities to identify, analyse and overcome hurdles to green procurement. Corp. Soc. Resp. Env. Ma. 13, 61-77.

\section{https://doi.org/10.1002/csr.92.}

Hall, P., Löfgren, K., and Peters, G., 2015. Greening the street-level procurer: Challenges in the strongly decentralized Swedish system. J. Consum. Policy. 39 (4), 467-483. https://doi.org/10.1007/s10603-0159282-8. 
Igarashi, M., de Boer, L., and Michelsen, O., 2015. Investigating the anatomy of supplier selection in green public procurement. J. Clean. Prod. 108, 442-450. https://doi.org/10.1016/j.jclepro.2015.08.010.

Igarashi, M., de Boer, L., and Pfuhl, G., 2017. Analyzing buyer behavior when selecting green criteria in public procurement. J. Public Procur. 17 (2), 141-186. https://doi.org/10.1108/JOPP-17-02-2017-B001.

ISO/TMBG Technical Management Board - groups., 2017. ISO 20400:2017 Sustainable procurement Guidance. Available at: https://www.iso.org/standard/63026.html (Accessed: 7/8 2018)

Leire, C. and Mont, O., 2010. The implementation of socially responsible purchasing. Corp. Soc. Resp. Env. Ma. 17 (1), 27-39. https://doi.org/10.1002/csr.198.

Lundberg, S. and Marklund, P-O., 2018. Green public procurement and multiple environmental objectives. J. Ind. Bus. Econ. 45 (1), 37-53. https://doi.org/10.1007/s40812-017-0085-6.

Marron, D., 2003. Greener public purchasing as an environmental policy instrument. J. Budget. 3 (4), 71 105. https://doi.org/10.1787/16812336.

McCrudden, C., 2004. Using public procurement to achieve social outcomes. Nat. Resour. Forum. 28, 257267. https://doi.org/10.1111/j.1477-8947.2004.00099.x.

McInnis, D.J., 2011. A framework for conceptual contributions in marketing. J. Marketing. 75,. 136-154. DOI:10.1509/jmkg.75.4.136.

Michelsen, O. and de Boer, L., 2009. Green procurement in Norway: A survey of practices at the municipal and county level. J. Environ. Manage. 91, 160-167. https://doi.org/10.1016/j.jenvman.2009.08.001.

Neto, B. and Caldas, M. G., 2018. The use of green criteria in the public procurement of food products and catering services: A review of EU schemes. Environ. Dev. Sustain. 20 (5), 1905-1933. http://dx.doi.org/10.1007/s10668-017-9992-y.

Noguchi, J., 2006. The science review article: An opportune genre in the construction of science. Ling. Insights. 17. Bern: Peter Lang. 
Oruezabala, G. and Rico, J-C., 2012. The impact of sustainable public procurement in supplier management

- The case of French public hospitals. Ind. Market. Manag. 41, 573-580.

http://dx.doi.org/10.1016/j.indmarman.2012.04.004.

Palmujoki, A., Parikka-Alhola, K. and Ekroos, A., 2010. Green public procurement: Analysis on the use of environmental criteria in contracts. Rev. Europ. Com. Int. Environ. Law. 19 (2), 250-262.

https://doi.org/10.1111/j.1467-9388.2010.00681.x.

Parikka-Alhola, K., 2008. Promoting environmentally sound furniture by green public procurement. Ecol.

Econ. 68, 472-485. https://doi.org/10.1016/j.ecolecon.2008.05.004.

Pearce, D.W. and Turner, R.K., 1990. Economics of natural resources and the environment. Hemel Hempstead, Hertforshire, UK: Harvester Wheatsheaf.

Preuss, L., 2009. Addressing sustainable development through public procurement: The case of local government. Supply Chain Manag. 14 (3), 213-223. https://doi.org/10.1108/13598540910954557.

Preuss, L. and Walker, H., 2011. Psychological barriers in the road to sustainable development: Evidence from public sector procurement. Public Admin. 89 (2), 493-521. https://doi.org/10.1111/j.14679299.2010.01893.x.

Prier, E., Schwerin, E. and McCue, C.P., 2016. Implementation of sustainable public procurement practices and policies: A sorting framework. J. Public Procur. 16 (3), 312-346. https://doi.org/10.1108/JOPP-16-032016-B004.

Rainville, A., 2017. Standards in green public procurement - A framework to enhance innovation. J. Clean. Prod. 167, 1029-1037. https://doi.org/10.1016/j.jclepro.2016.10.088.

Rakitovac, K.A. and Simokov, I.V., 2011. Promoting sustainable development through public procurement. Sustain. Dev. 1342-1591. https://www.jstor.org/stable/44742587. 
Roman, A.V., 2017. Institutionalizing sustainability: A structural equation model of sustainable procurement in US public agencies. J. Clean. Prod. 143, 1048-1059. https://doi.org/10.1016/j.jclepro.2016.12.014.

Rousseau, D.M., Manning, J., and Denyer, D., 2008. Evidence in management and organizational sciences: assembling the field's full weight of scientific knowledge through syntheses. A. Acad. Manag. 2, 475-515.

Ringberg, T. and Gupta, S.F., 2003. The importance of understanding the symbolic world of customers in asymmetric business-to-business relationships. J. Bus. Ind. Mark. 18 (6/7), 607-626. https://doi.org/10.1108/08858620310492455.

Ritzén, S. and Sandström, G.Ö., 2017. Barriers of the circular economy - Integration of perspectives and domains. Procedia. 64, 7-12, The 9th CIRP IPSS Conference: Circular Perspectives on Product/Service/Systems. https://doi.org/10.1016/j.procir.2017.03.005.

Sachs, J., Schmidt-Traub, G., Kroll, C., Durand-Delace, D., and Teksoz, K., 2017. SGD index and dashboard report 2017. New York: Bertelsmann Stiftung and Sustainable Development Solutions Network (SDSN). Available at: http://sdgindex.org/reports/2017/

Saldana, J., 2013. The coding manual for qualitative researchers, Second Edition. London: SAGE Publications.

Seuring, S. and Muller, M., 2008. From a literature review to a conceptual framework for sustainable supply chain management. J. Clean. Prod. 16, 1699-1710. https://doi.org/10.1016/j.jclepro.2008.04.020.

Schebesta, H., 2018. Revision of the EU green public procurement criteria for food procurement and catering services - Certification schemes as the main determinant for public sustainable food purchases? Eur. J. Risk Reg. 9, 316-328. http://dx.doi.org/10.1017/err.2018.24.

Schlosser, R.W. 2006. The Role of Systematic Reviews in Evidence-Base Practice, Research and Development, National Center for the Dissemination of Disability Research, Technical brief, (15), 1-4. 
Smith, J., Andersson, G., Gourlay, R., Karner, S., Mikkelsen, B.E., Sonnino, R., and Barling, D., 2016. Balancing competing policy demands: The case of sustainable public sector food procurement. J. Clean. Prod. 112, 249-256. https://doi.org/10.1016/j.jclepro.2015.07.065.

Sonnino, R., 2009. Quality food, public procurement, and sustainable development: The school meal revolution in Rome. Environ. Plann. 41, 425-440. https://doi.org/10.1068\%2Fa40112.

Sourani, A. and Sohail, M., 2011. Barriers to addressing sustainable construction in public procurement strategies. Loughborough University Institutional Repository, 164 (4), 229-237. DOI: $\underline{10.1680 / \text { ensu.2011.164.4.229. }}$

Sparrevik, M., Wangen, H.F., Fet, A.M., and De Boer, L., 2018. Green public procurement - A case study of an innovative building project in Norway. J. Clean. Prod. 188, 879-887.

https://doi.org/10.1016/j.jclepro.2018.04.048.

Sporrong, J. and Bröchner, J., 2009. Public procurement incentives for sustainable design services: Swedish experiences. Archit. Eng. Design Manag. 5, 24-35. http://dx.doi.org/10.3763/aedm.2009.0903

Tarantini, M., Loprieno, A.D., and Porta, P.L., 2011. A life cycle approach to green public procurement of building materials and elements: A case study on windows. Energy. 36, 2473-2482.

https://doi.org/10.1016/j.energy.2011.01.039.

Testa, F., Iraldo, F., Frey, M., and Daddi, T., 2012. What factors influence the uptake of green public procurement practices? New evidence from an Italian survey. Ecol. Econ. 82, 88-96. https://doi.org/10.1016/j.ecolecon.2012.07.011.

Testa, F., Annunziata, A., Iraldo, F., and Frey, M., 2016a. Drawbacks and opportunities of green public procurement: An effective tool for sustainable production. J. Clean. Prod. 112, 1893-1900. https://doi.org/10.1016/j.jclepro.2014.09.092. 
Testa, F., Grappio, P., Gusmerotti, N., Iraldo, F. and Frey, M., 2016b. Examining green public procurement using content analysis: Existing difficulties for procurers and useful recommendations. Env. Dev. Sustain. 18, pp. 197-219. https://doi.org/10.1007/s10668-015-9634-1.

United Nations Environment Programme, 2013. Sustainable public procurement: A global review, final report. Available at: https://globalecolabelling.net/assets/Documents/unep-spp-report.pdf (Accessed: 6/5 2018)

United Nations Environment Programme, 2017. Global review of sustainable public procurement. Available at:

https://wedocs.unep.org/bitstream/handle/20.500.11822/20919/GlobalReview_Sust_Procurement.pdf?sequen ce $=1 \&$ isAllowed $=\mathrm{y}($ Accessed: $6 / 6$ 2018)

Uttam, K. and Roos, C.L.L., 2015. Competitive dialogue procedure for sustainable public procurement. J. Clean. Prod. 86, pp. 403-416. https://doi.org/10.1016/j.jclepro.2014.08.031.

Walker, H. and Brammer, S., 2009. Sustainable procurement in the United Kingdom public sector. Supply Chain Manag. 14 (2), 128-137. https://doi.org/10.1108/13598540910941993.

Webster, K., 2017. The circular economy: A wealth of flows $-2^{\text {nd }}$ edition. Isle of Wight, UK: Ellen MacArthur Foundation Publishing.

Witjes, S. and Lozano, R., 2016. Towards a more circular economy: Proposing a framework linking sustainable public procurement and sustainable business models. Resour. Conserv. Recy. 112, 37-44. https://doi.org/10.1016/j.resconrec.2016.04.015.

World Commission on Environment and Development, 1987. Report of the World Commission on Environment and Development: Our common future. Available at: http://www.un-documents.net/ourcommon-future.pdf (Accessed: 6/4 2018) 
Zvaigzdiniene, I. and Rudauskiene, R., 2012. Protecting the environment through public procurement:

Lithuania’s case. Bus. Law. 4, 48-58. http://dx.doi.org/10.5200/ib1.2012.05. 